\title{
Chapter 4 \\ Cancer of Reproductive System: Receptors and Targeting Strategies
}

\author{
Manish Gore, Amita Puranik, Abhishek Indurkar, Bismita Sonowal, \\ Padma V. Devarajan, Ratnesh Jain, and Prajakta Dandekar
}

\begin{abstract}
Carcinogenesis in the different organs of the reproductive system, particularly, prostate, ovarian, and cervical tissues, involves aberrant expression of various physiological receptors belonging to different superfamilies. This chapter provides insights into the physiological receptors that are associated with the genesis, progression, metastasis, management, as well as the prognosis of the cancers of the male and female reproductive systems. It also highlights the structural and binding characteristics of the highly predominant receptors, namely, androgen, estrogen, progesterone, and gonadotropin-releasing hormone $(\mathrm{GnRH})$ receptors, which are overexpressed in these cancers and discusses various strategies to target them.
\end{abstract}

Keywords Reproductive - Cancers · Prostate - Ovarian · Cervical · Receptors · Structure $\cdot$ Binding $\cdot$ Target

\section{Abbreviations}

5-A DHT 5A-di-hydro testosterone

$\mathrm{AD} \quad$ Adenovirus

ADC Antibody-drug conjugates

AIs Aromatase inhibitors

ARE Androgen response elements

M. Gore · A. Indurkar · B. Sonowal

Department of Pharmaceutical Sciences \& Technology, Institute of Chemical Technology, Mumbai, India

P. V. Devarajan · P. Dandekar $(\bowtie)$

Department of Pharmaceutical Sciences, Insitute of Chemical Technology, Deemed University, Elite Status and Centre of Excellence, Government of Maharashtra, Mumbai, India e-mail:pd.jain@ictmumbai.edu.in
A. Puranik · R. Jain $(\bowtie)$
Department of Chemical Engineering, Institute of Chemical Technology, Mumbai, India
e-mail: rd.jain@ictmumbai.edu.in 


\begin{tabular}{|c|c|}
\hline $\mathrm{BPH}$ & Benign prostate hyperplasia \\
\hline CDK & Cyclin-dependent kinase \\
\hline CNS & Central nervous system \\
\hline CRPC & Castrate-resistant prostate cancer \\
\hline DBD & DNA-binding domain \\
\hline DOX & Doxorubicin \\
\hline E2 & Estradiol \\
\hline EGF & Epidermal growth factor \\
\hline EGFR & Epidermal growth factor receptor \\
\hline EOC & Endometrial ovarian cancer \\
\hline ER & Estrogen receptor \\
\hline ERE & Estrogen response elements \\
\hline FSH & Follicle-stimulating hormone \\
\hline FSHR & Follicle-stimulating hormone receptor \\
\hline GLU & Glutamate \\
\hline GNRH & Gonadotropin-releasing hormone \\
\hline GNRHR & Gonadotropin-releasing hormone receptor \\
\hline GPCR & G-protein-coupled receptor \\
\hline GPER & G-protein estrogen receptor \\
\hline HER-2 & Human epidermal growth factor receptor- 2 \\
\hline HPG & Hypothalamic-pituitary gonadal (axis) \\
\hline HPV & Human papilloma virus \\
\hline HRE & Hormone response elements \\
\hline HSP & Heat shock proteins \\
\hline i.m. & Intramuscular \\
\hline LBD & Ligand-binding domain \\
\hline LBP & Ligand-binding pocket \\
\hline LH & Luteinizing hormone \\
\hline LHR & Luteinizing hormone receptor \\
\hline mAbs & Monoclonal antibodies \\
\hline MCRPC & Metastatic castrate-resistant prostate cancer \\
\hline NLS & Nuclear localization signal \\
\hline NTD & $\mathrm{N}$-terminal transcription regulational domain \\
\hline P4 & Progesterone \\
\hline PR & Progesterone receptor \\
\hline PRB & Retinoblastoma protein \\
\hline PRE & Progesterone response elements \\
\hline PSA & Prostate-specific antigen \\
\hline PSGR & Prostate-specific G-protein-coupled receptor \\
\hline PSMA & Prostate-specific membrane antigen \\
\hline PSMAA & Prostate-specific membrane aptamers \\
\hline RES & Reticulo-endothelial system \\
\hline RP2D & Recommended phase 2 dose \\
\hline
\end{tabular}




$\begin{array}{ll}\text { s.c. } & \text { Subcutaneous } \\ \text { SAR } & \text { Structure-activity relationships } \\ \text { SARM } & \text { Selective androgen receptor modulators } \\ \text { SCID } & \text { Severe combined immunodeficiency } \\ \text { SERM } & \text { Selective estrogen receptor modulators } \\ \text { SMA } & \text { Styrene-maleic scid } \\ \text { SMA-RAL } & \text { SMA-encapsulated raloxifene } \\ \text { SPRM } & \text { Selective progesterone receptor modulators } \\ \text { TMD } & \text { Transmembrane domain }\end{array}$

\section{Introduction: Reproductive System-Related Cancers}

Cervical and ovarian cancers are the fourth most and the seventh most common cancers in women, with a global prevalence of approximately 3.7 percent and 1.7 percent, respectively [1-3]. The prostate cancer is considered as the fifth leading cause of cancer-associated mortality in men, with a global prevalence of about 7.9 percent $[3,4]$. The risk factors for cancers related to reproductive system include but not limited to endogenous factors such as genetic history, race, aging, hormonal imbalance, and exogenous factors such as inappropriate diet, unhealthy lifestyle, and environmental and occupational factors. Moreover, cervical cancer risk factors are extended to the infection of human papilloma virus (HPV), extended usage of contraceptives, age of menarche and menopause, unsafe sexual activities such as sexual intercourse at an early stage and multiple sexual partners [1,5-12]. This chapter provides a detailed overview of the structural, pharmaceutical, and clinical aspects of the agents discovered to target the dominant receptors involved in the development, treatment, and prognosis of the reproductive neoplasia.

\section{Overview: Receptors Associated with the Cancers of the Reproductive System}

Table 4.1 lists the receptors that are ubiquitous in various cancers of the reproductive system, specifically during their prognosis, diagnosis, progression, and therapy.

The subsequent discussion is focused on four principal receptors that display a significant expression pattern during the genesis, diagnosis, treatment, and prognosis of the reproductive neoplasia. 
Table 4.1 Receptors associated with the prognosis, diagnosis, progression, and therapy of the cancers of the reproductive system

\begin{tabular}{|c|c|c|c|}
\hline Type of receptors & Cervical cancer & Ovarian cancer & Prostate cancer \\
\hline $\begin{array}{l}\text { Ion channel } \\
\text { receptors } \\
\text { (inotropic) }\end{array}$ & $\begin{array}{l}\text { P2 receptors: P2X4, } \\
\text { P2X7 [13-15] }\end{array}$ & $\begin{array}{l}\text { P2 receptors: } \mathrm{P} 2 \mathrm{X} 7 \\
{[13,14]}\end{array}$ & $\begin{array}{l}\text { P2 receptors: } \mathrm{P} 2 \mathrm{X} 4, \\
\text { P2X5, } \mathrm{P} 2 \mathrm{X} 7[13,14] \\
\text { NMDA (N-methyl-D- } \\
\text { aspartate) receptor }[16] \\
\text { GABAa receptor }[17]\end{array}$ \\
\hline $\begin{array}{l}\text { G-protein-coupled } \\
\text { receptors (GPCRs) } \\
\text { (metabotropic) }\end{array}$ & $\begin{array}{l}\text { Endothelin-1: }\left(\mathrm{ET}_{\mathrm{A}} \mathrm{R}\right) \\
{[18-20]} \\
\text { Protease-activated } \\
\text { receptor-2 (PAR-2) } \\
{[21]} \\
\text { Gastrin-releasing } \\
\text { peptide receptor } \\
\text { (GRPR) [22, 23] } \\
\text { G-protein-coupled } \\
\text { estrogen receptor-1 } \\
\text { (GPER-1) - prognostic } \\
\text { maker for early-stage } \\
\text { cancer [7] } \\
\text { Folate receptor subtype } \\
\text { alpha }(\mathrm{FR} \alpha)[24]\end{array}$ & $\begin{array}{l}\text { Endothelin-1: }\left(\mathrm{ET}_{\mathrm{A}} \mathrm{R}\right) \\
{[19,25,26]} \\
\text { Protease-activated } \\
\text { receptor-1 and 2 (PAR } \\
1 \text { and 2) [27, 28] } \\
\beta \text {-Adrenergic receptor } \\
\text { [29] } \\
\text { Gastrin-releasing } \\
\text { peptide receptor } \\
\text { (GRPR) [30, 31] } \\
\text { G-protein-coupled } \\
\text { estrogen receptor-1 } \\
\text { (GPER-1) [32, 33] } \\
\text { Folate receptor-FR } \alpha \\
\text { and Reduced Folate } \\
\text { Carrier (RFC) [34] } \\
\text { Follicle-stimulating } \\
\text { hormone receptor } \\
\text { (FSHR) } \\
\text { Luteinizing hormone } \\
\text { receptor (LHR) } \\
\text { Gonadotropin- } \\
\text { releasing hormone } \\
\text { receptor (GnRHR) } \\
\text { Thyroid-stimulating } \\
\text { hormone receptor } \\
\text { (TSHR) } \\
\text { Kisspeptin receptor } \\
\text { Angiotensin II type 1 } \\
\text { receptor [2] } \\
\text { Serotonin (5-HT) } \\
\text { receptors - 5-HTR1A, } \\
\text { 5-HTR1RB, } \\
\text { 5-HTR2B, 5-HTR4 } \\
\text { [35] }\end{array}$ & $\begin{array}{l}\text { Endothelin-1: }\left(\mathrm{ET}_{\mathrm{A}} \mathrm{R}\right) \\
{[19,36,37]} \\
\text { Protease-activated } \\
\text { receptor-1, 2, and 4 } \\
\text { (PAR-1, 2, and 4) } \\
\text { [38-40] } \\
\beta \text {-Adrenergic receptor } \\
\text { [29, 41] } \\
\text { Gastrin-releasing peptide } \\
\text { receptor (GRPR) [31, 42] } \\
\text { G-protein-coupled } \\
\text { estrogen receptor-1 } \\
\text { (GPER-1) [33] } \\
\text { Prostate-specific } \\
\text { G-protein-coupled } \\
\text { receptor (PSGR)-PSGR2 } \\
\text { [43, 44] } \\
\text { G-protein-coupled } \\
\text { receptor-158 (GPR158) } \\
\text { [45] } \\
\text { Lysophosphatidic acid } \\
\text { (LPA)-1 receptor [46] } \\
\text { Gonadotropin-releasing } \\
\text { hormone receptor } \\
\text { (GnRHR) [47] } \\
\text { Serotonin (5-HT) } \\
\text { receptors - 5-HTR1A, } \\
\text { 5-HTR1RB, 5-HTR2B, } \\
\text { 5-HTR4 [48, 49] }\end{array}$ \\
\hline
\end{tabular}


Table 4.1 (continued)

\begin{tabular}{|c|c|c|c|}
\hline Type of receptors & Cervical cancer & Ovarian cancer & Prostate cancer \\
\hline $\begin{array}{l}\text { Tyrosine kinase } \\
\text { receptors }\end{array}$ & $\begin{array}{l}\text { Human epidermal } \\
\text { growth factor receptor } \\
\text { (HER-2)/neu [50] } \\
\text { Epidermal growth } \\
\text { factor receptor (EGFR) } \\
\text { [51] } \\
\text { Insulin-like growth } \\
\text { factor-I receptor } \\
\text { (IGF-IR) [52] } \\
\text { Vascular endothelial } \\
\text { growth factor (VEGF) } \\
\text { receptor [53] } \\
\text { Prolactin receptor } \\
\text { (PRLR) [54] } \\
\text { Hepatocyte growth } \\
\text { factor/(cMET) [55] } \\
\text { Fibroblast growth } \\
\text { factor receptor (FGFR) } \\
\text { [56] }\end{array}$ & $\begin{array}{l}\text { HER-2/neu receptor } \\
\text { [57] } \\
\text { Epidermal growth } \\
\text { factor receptor } \\
\text { (EGFR) [58] } \\
\text { Insulin-like growth } \\
\text { factor-I receptor } \\
\text { (IGF-IR) [59] } \\
\text { Vascular endothelial } \\
\text { growth factor (VEGF) } \\
\text { receptor [53] } \\
\text { Hepatocyte growth } \\
\text { factor/(cMET) [60] } \\
\text { Fibroblast growth } \\
\text { factor receptor } \\
\text { (FGFR) [61] }\end{array}$ & $\begin{array}{l}\text { HER-2/neu receptor [62] } \\
\text { Epidermal growth factor } \\
\text { receptor (EGFR) [63] } \\
\text { Insulin-like growth } \\
\text { factor-I receptor } \\
\text { (IGF-IR) [64] } \\
\text { Vascular endothelial } \\
\text { growth factor (VEGF) } \\
\text { receptor [65] } \\
\text { Hepatocyte growth } \\
\text { factor/(cMET) [60] } \\
\text { Fibroblast growth factor } \\
\text { receptor (FGFR) [66] }\end{array}$ \\
\hline Nuclear receptors & $\begin{array}{l}\text { Estrogen receptor }(\mathrm{ER} \alpha \\
\text { and } \mathrm{ER} \beta) \\
\text { Progesterone receptor } \\
\text { (PR): PR-A, PR-B [1] } \\
\text { Vitamin-D receptor } \\
\text { (VDR) [67] } \\
\text { Retinoic acid receptor } \\
\beta[68]\end{array}$ & $\begin{array}{l}\text { Estrogen receptor } \\
(\mathrm{ER} \alpha \text { and } \mathrm{ER} \beta) \\
\text { Progesterone receptor } \\
(\mathrm{PR}) \text { : PR-A, PR-B [1, } \\
69] \\
\text { Androgen receptor } \\
(\mathrm{AR}) \\
\text { Vitamin-D receptor } \\
\text { (VDR) [67] } \\
\text { Retinoic acid receptor } \\
{[70]}\end{array}$ & $\begin{array}{l}\text { Androgen receptor (AR) } \\
{[71]} \\
\text { Estrogen receptor (ER } \beta) \\
{[72]} \\
\text { Progesterone receptor } \\
\text { (PR) [73] } \\
\text { Peroxisome proliferator- } \\
\text { activated receptor- } \\
\text { Gamma (PPAR } \gamma \text { ) }[74]\end{array}$ \\
\hline
\end{tabular}

\section{Predominant Receptors in Reproductive System-Related Cancers}

\subsection{Nuclear Receptors}

Nuclear receptors comprise a family of transcription factors that get activated due to the binding of the lipophilic ligands, to carry out reproduction, development, homeostasis, and metabolism. They act by responding to the signals generated by the steroid hormones and regulate the expression of the target genes [75-77].

\subsubsection{Steroid Sex Hormone Receptors}

The organs of the reproductive system serve as the primary sites of action of sex steroid hormones, such as the estrogen, progesterone, and androgen. These hormones are responsible for mediating the developmental activities and physiological 
functions of the male and female reproductive systems. They exert their functions through the action of steroid hormone receptors, namely, the estrogen (ER), progesterone (PR), and androgen (AR) receptors, respectively. Aberrations in their expression and/or in the factors regulating them, termed as coregulators, lead to either activation or suppression of their transcription machinery, eventually impacting their physiological functions. These abnormalities trigger a cascade of pathological changes in vivo, thereby resulting into carcinogenesis [78, 79].

ER-subtype $\alpha(E R \alpha)$ and PR receptors play a pivotal role in the pathophysiology of cervical cancer. The PRs were found to exhibit tumor-suppressive properties in cervical cancer $[1,7]$. In the case of ovarian malignancy, ER $\alpha$ expression provided a better prognosis, while the role of ER $\beta$ was insignificant. On the other hand, an elevated PR expression was observed to improve the survival rate in patients with endometrial ovarian cancer (EOC) [80]. The activity of AR has been closely linked to the prostatic carcinogenesis. The biochemical pathway of AR, the principal regulator of prostatic cancer, is perturbed during the carcinogenesis. Castration-resistant prostate cancer (CRPC), an advanced stage of the disease which is nonresponsive to hormone deprivation therapy, occurs due to increase in sensitivity of the AR to the agonists, mutations in the receptor, ligand-independent activation of the ARs, etc. [71]

\subsection{G-Protein-Coupled Receptors}

\subsubsection{Gonadotropin-Releasing Hormone Receptor (GnRHR)}

GnRH-I, produced in vivo, by the GnRHR (located in the hypothalamus) stimulates the secretion of the gonadotropins, namely the luteinizing hormone (LH) and the follicle-stimulating hormone (FSH), which further regulate the in vivo levels of sex hormones [81]. The GnRHR is also expressed in the CRPC [82]. Primary cultures of ovarian carcinomas and biopsy specimens of malignant ovarian tissue have revealed the predominant expression of the GnRHR receptor $(>80 \%)$, signifying its role in the genesis of malignancy and metastasis. The GnRHR has also been speculated to be associated with the early phases of ovarian carcinogenesis, including cell migration and invasion [83]. It was observed that administration of GnRH-1 agonists and antagonists lead to the downregulation and inactivation of GnRHR, respectively. As a result, the GnRH agonists cause inhibition of cell proliferation, metastasis, and angiogenesis. Moreover, the $\mathrm{GnRH}$ antagonists also possess antineoplastic activity [81, 82]. Thus, exploration of the structure and regulation of the GnRHRs in cancers of the reproductive system may enhance their applicability, as a target receptor, for the discovery of new-age anticancer therapeutics.

Understanding the structure and the binding chemistries of these receptors and reviewing the potential of targeting it may pave the way to the discovery of the breakthrough anticancer therapies in the near future. 


\section{Predominant Receptors in Cancers Related to Reproductive System: Structural Attributes}

\subsection{Androgen Receptor}

Androgen receptor (AR), a 110-kDa protein, is a ligand-activated transcription factor belonging to the family of steroid hormone nuclear receptors [71]. AR, expressed in prostate, is activated by binding of endogenous androgens, such as testosterone and $5 \alpha$-dihydrotestosterone ( $5 \alpha$-DHT). Functional AR is responsible for in vivo male sexual differentiation and occurrence of pubertal changes [84].

This receptor mediates normal growth and development of the prostate gland and also plays a vital role in the prostatic carcinogenesis and its progression to an androgen-independent disease. Androgen-independent stage of prostate cancer (e.g., CRPC) has been observed due to the activation of the AR receptor by overexpression of gene and cofactors, gene mutations, splice variants, and intracrine synthesis of androgen [85, 86]. In addition, AR is also expressed in the different subtypes of ovarian and cervical cancers $[87,88]$.

\subsubsection{Androgen Receptor: Recognition Domain and Receptor Pathway}

The AR modular protein consists of four distinct domains, namely, the ligandbinding domain (LBD), the hinge domain, the DNA-binding domain (DBD), and the N-terminal transcriptional regulation/amino-terminal domain (NTD). NTD is the most variable region, whereas DBD and LBD are highly conserved among different receptors of the steroid hormone nuclear receptor family. The LBD, the key recognition domain of $\mathrm{AR}$, is arranged in three layers and comprises eleven $\alpha$-helices, particularly, $\mathrm{H} 1-\mathrm{H} 11$, except $\mathrm{H} 2$, which results into formation of an antiparallel " $\alpha$-helical sandwich." The ligand-binding pocket (LBP) is formed by H5, C-terminal of H10 and H11, and N-terminal of H3. The activation function (AF)-1, located at the $\mathrm{N}$-terminal, is not conserved in the sequence and is ligand-independent, whereas AF-2, at the C-terminal, is conserved and ligand-dependent. The nuclear localization signal (NLS) is located between the DBD and the hinge region [71, 89, 90].

\section{The Genomic Pathway of AR}

Unbound AR exists in an inactive state in the cytoplasm, in complexation with the heat shock proteins (HSP) such as HSP90. Upon binding to a ligand/agonist, it gets activated and dissociates from the HSP and undergoes dimerization and phosphorylation. Binding of an agonist leads to the formation of the AF-2 region on the surface of LBD. Upon ligand binding, AF-2 interacts with the amino-terminal motifs of the receptor, which leads to an establishment of N/C intradomain crosstalk, thereby leading to receptor stabilization, enhanced DNA-binding affinity, and 
reduced ligand dissociation, a phenomenon exclusively observed in the AR, unlike other steroid receptors. AF-2 domain also recruits coregulatory proteins to an activated $\mathrm{AR}$, thereby contributing to its overall function. H12, the core structure of AF-2, acts as a lid to close LBP, upon binding of the agonist. Further, the NLS gets exposed upon the ligand/agonist binding and interacts with importin- $\alpha$. This leads to translocation of AR from cytoplasm to the nucleus. DBD facilitates interaction of the translocated receptor with the DNA at specific recognition sites. These sites, located in the promoter and enhancer regions of the AR target genes, consist of consensus sequences and are termed as androgen response elements (ARE). Access of AR to the target chromatin requires concerted action of certain transcription factors. AF-1 and AF-5 of NTD mediate the transcriptional activity by recruitment of coactivator complexes and transcription machinery, essential to regulate the expression of the target genes. Selective recognition of specific ARE sequences is regulated by the ligand-binding and/or presence of other transcription factors [84, 89-91]. Figure 4.1a provides a schematic layout of the structure of the steroid receptor (SR) and its pathway of transactivation after binding of the ligand.

\subsubsection{Ligands and Their Structure-Activity Relationships (SAR) for Selective Binding to AR}

Ligands modulate their action by binding to the LBP of LBD. The AR is capable to accommodate a large variety of ligands by modifying the volume of LBP [71]. Testosterone (Fig. 4.2a) and DHT (Fig. 4.2b) are the physiological ligands of the AR [89]. Carbon atoms of the testosterone skeleton have been numbered in order to provide basis for the SARs with various ligands and their derivatives [71]. Synthetic derivatives of testosterone have been prepared to enhance oral bioavailability. It is essential for the ligand (natural/synthetic) to contain a steroidal skeleton for retaining the androgenic activity. Hydrophobic amino acid residues in the LBP interact with the steroid scaffold. A/B ring junction usually has "trans" stereochemistry. $17 \beta-\mathrm{OH}$ atom is essential for ligand-receptor interaction via formation of a hydrogen bond with the amino acid residues [71, 89].

Fig. 4.1 (a) Schematic of the structure and genomic pathway of the Steroid Receptor (SR) activated upon binding of the ligand (e.g., hormone). Binding of the ligand causes activation of the HSP-90-bound SR that undergoes nuclear translocation, dimerization, and then binds to the hormone response elements (HRE) by the action of cofactors/coactivators, thus resulting into transactivation and transcription of the target genes. The enlarged view of the SR reveals different structural domains, namely, N-terminal domain (NTD), DNA-binding domain (DBD), Hinge region $(\mathrm{H})$, and ligand-binding domain $(\mathrm{LBD})$, wherein each domain is capped by $\mathrm{N}$-termini and C-termini amino acid residues. Presence of NLS, AF-1, and AF-2 domains has also been indicated. (b) Schematic representation of GnRHR and intracellular pathway activated on binding of GnRH. Binding of the ligand activates the receptor. The latter binds to GTP-linked proteins, or G-proteins. Goq/11, a subunit of G-proteins, activates phospholipase C, which then hydrolyzes phosphatidylinositol-4,5-bisphosphate (PIP2) to inositol triphosphate (IP3) and diacylglycerol (DAG). DAG activates protein kinase C (PKC), further leading to cascade of intracellular events, operating through activation of phospholipase A2, ultimately leading to Gonadotropin biosynthesis and release 


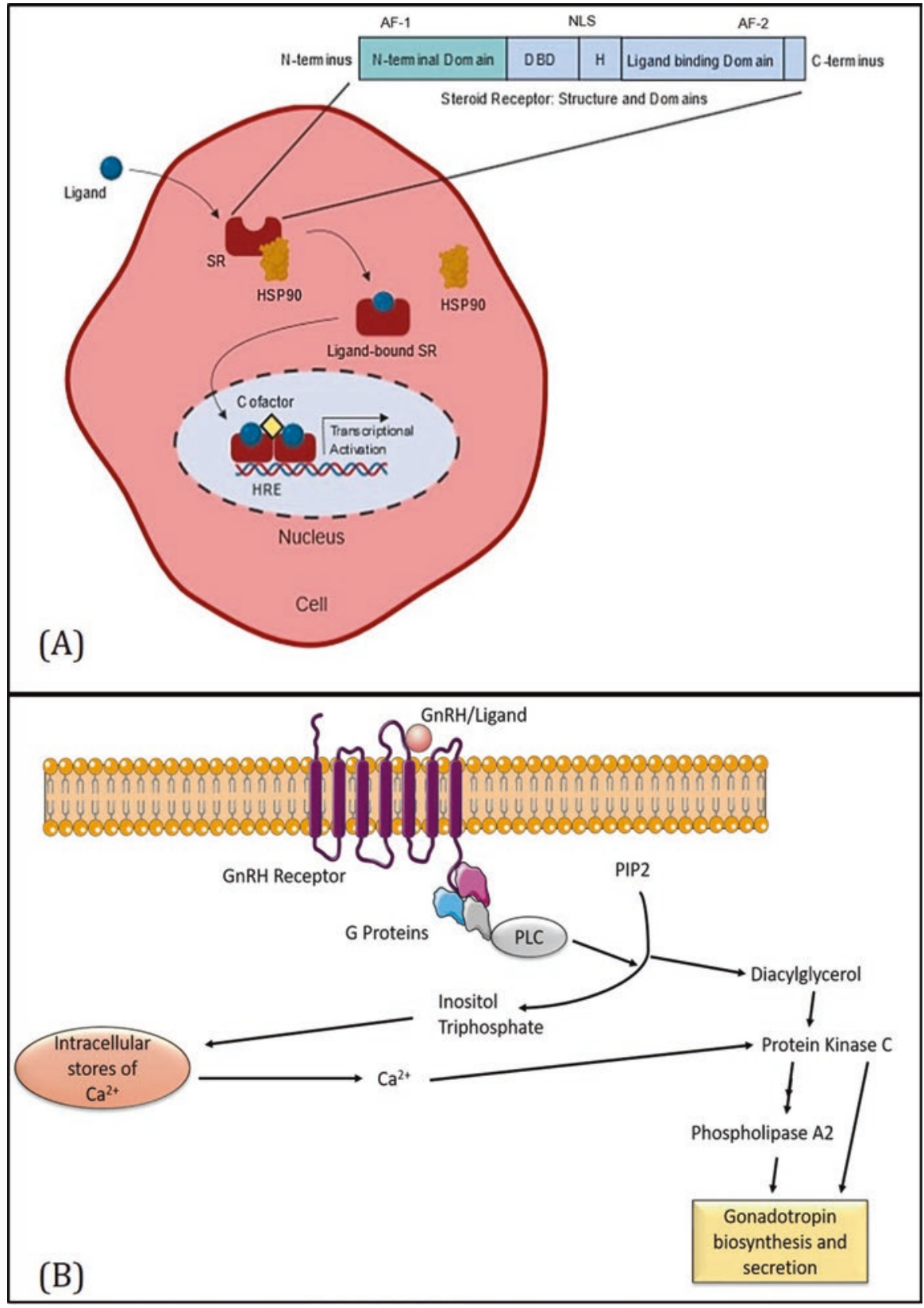

Fig. 4.1 (Caption on p. 116) 


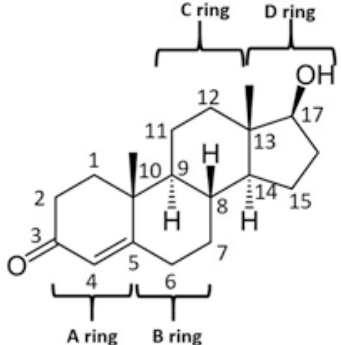

(A) Testosterone

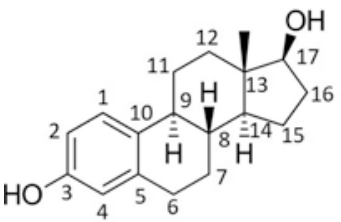

(D) Estradiol (E2)

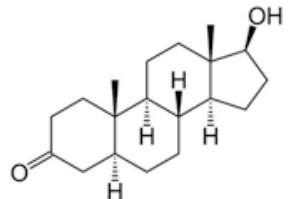

(B) Dihydrotestosterone (DHT)

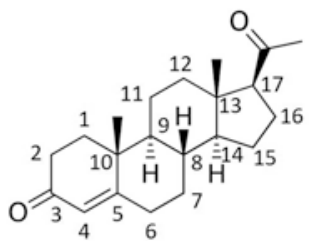

(E) Progesterone (P4)

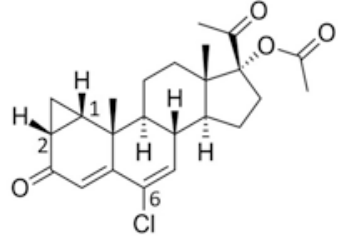

(C) Cyproterone Acetate

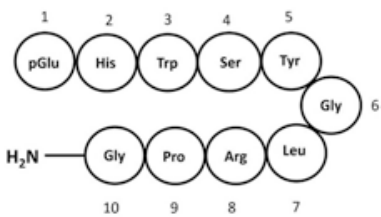

(F) GnRH Decapeptide

Fig. 4.2 Structure of ligands/chemical agents and action on the predominant receptors of cancers of the reproductive system. Carbon atoms and hydrophobic rings have been numbered wherever necessary. (a) Testosterone, (b) Dihydrotestosterone, (c) Cyproterone acetate, (d) Estradiol (E2), (e) Progesterone (P4), and (f) GnRH decapeptide

\subsection{Estrogen Receptor}

Estrogens naturally occur in three different forms in females, namely, estradiol (E2) (Fig. 4.2d), estriol, and estrone. It exerts its action through the estrogen receptors (ERs), which belong to the steroid hormone superfamily of nuclear receptors. ERs, occurring in two forms, ER- $\alpha$ and ER- $\beta$, act as ligand-activated transcription factors, upon binding to the endogenous ligands [92-94]. Expression of estrogen and its receptors have been very well documented in prostate, ovarian, and cervical cancers. ER- $\alpha$ and ER- $\beta$ have been reported to play oncogenic and antioncogenic roles in the pathogenesis of prostate cancer. The aberrant expression of the enzymes involved in steroid biosynthesis and metabolism, such as aromatase and 5- $\alpha$ reductase, has also been implicated in prostatic malignancy $[72,95]$. This chapter will further provide insights into the structural aspects of the receptor and its SAR with the ligands.

\subsubsection{Recognition Domain and Receptor Pathway of ER}

ER- $\alpha$ (66-kDa protein) is predominantly expressed in the reproductive tract, whereas ER- $\beta$ (54-kDa protein) primarily occurs in the vascular endothelial cells, bones, and male prostatic tissues. The ER receptor consists of an NTD, DBD, 
hinge region, and LBD. The NTD stimulates transcription from particular estrogen-responsive promoters via AF-1. DBD binds to estrogen response elements (ERE) in the target DNA, while the hinge region contains nuclear NLS. The LBD and AF-2 activate the gene expression in response to ligand binding. The classical genomic pathway results in the formation of estrogen-dependent, nuclear ER homo- or heterodimers, such as ER- $\alpha /$ ER- $\alpha$, ER- $\beta / E R-\beta$, and ER- $\alpha / E R-\beta$, respectively. Further, these dimers subsequently bind to the estrogen response element (ERE) sequences located in the promoter region of estrogen-responsive genes, resulting in the recruitment of coregulatory proteins (coactivators or corepressors) to the promoter. This leads to either an enhancement or reduction in the mRNA levels, further impacting the production of associated proteins and eventually the physiological response $[89,96]$.

\subsubsection{Ligands and Their Structure-Activity Relationships for Selective Binding to ER}

A vast array of compounds acting as ligands for the ER- $\alpha$ and ER- $\beta$ receptors have been classified as endo-estrogens (E2), phytoestrogens (Resveratrol), xenoestrogens (Mestranol), metalloestrogens (copper $\left(\mathrm{Cu}^{2+}\right)$, etc. [89, 97, 98].

Recognition of the binding of endo-estrogen (E2) to ER is achieved partly by intermolecular hydrogen binding and van der Waals interactions with the receptor [97]. The aromatic A ring, C-3 and $17 \beta$ hydroxyl groups and the distance between them, and planar hydrophobic structure are essential for estrogenic activity. On the other hand, substitution at C-1, hydroxylation at C-6, 7, and 11, removal of oxygen from $\mathrm{C}-3$ or $\mathrm{C}$-17, and epimerization of $17-\beta$-hydroxyl group of $\mathrm{E} 2$ to $\alpha$-configuration lead to reduction in the activity $[89,99]$.

\subsection{Progesterone Receptor}

Progesterone (P4; represented in Fig. 4.2e) and progesterone receptors (PRs) are necessary for the development of hormone-responsive tissues such as breasts and other organs of the reproductive tract. It is responsible for ovulation, embryo implantation, pregnancy, development of the mammary gland, and sexual differentiation and behavior. The hormone inhibits the proliferative action of estrogen in the reproductive tissues, such as endometrium and ovary, thus preventing them from undergoing neoplastic transformation [100, 101]. PRs, existing as two isoforms, namely PR-A ((molecular weight of $94 \mathrm{kDa})$ and PR-B (molecular weight of $114 \mathrm{kDa}$ ), are ligand-activated transcription factors, belonging to the superfamily of steroid hormone nuclear receptors. PR-B is referred to as full length and dominant receptor, while PR-A is the N-terminal truncated version [102, 103]. Both the isoforms suppress proliferation of the prostate stromal and cervical cancer cells $[1,104]$. PR overexpression is associated with favorable prognosis in women with ovarian malignancies [105]. 


\subsubsection{Recognition Domain and Receptor Pathway of PR}

The PR receptors share common structural elements with other steroid receptors, namely, NTD, DBD, hinge region, and LBD. The NTD is responsible for ligandindependent transcriptional activation and harbors a highly variable AF-1 domain. The DBD binds to the progesterone response elements (PREs) located in the target DNA. The hinge region contains NLS, while the LBD and a highly conserved AF-2 domain are responsible for the ligand-mediated transactivation of the gene expression, via the genomic pathway. The LBD or the primary recognition domain comprises a hydrophobic LBP, to facilitate ligand binding. The genomic pathway operates on binding of $\mathrm{P} 4$, which causes conformational change in the PR, thereby transforming it into an active transcriptional factor. As a result, receptor phosphorylation occurs and the PR undergoes dimerization (homo/hetero) and nuclear translocation, to further interact with the PREs. This also leads to the recruitment of coactivators that mediate gene transcription. It has been reported that PR-A and PR-B possess opposite transcriptional activities and the overall response of $\mathrm{P} 4$ is dependent on the relative in vivo levels of PR-A and PR-B. 5 $\alpha$-reductase and 20 $\alpha$-hydroxysteroid dehydrogenase are responsible for the metabolic conversion of $\mathrm{P} 4$ to a more active or less active form, before interaction with the receptors in the target cells $[89,102,106]$.

\subsubsection{Ligands and Structure-Activity Relationships for Selective Binding to $\mathbf{P R}$}

$\mathrm{P} 4$ is an endogenous ligand of the PR receptors. The progestin activity is confined to the molecules having a steroid nucleus. The synthetic progestins have been categorized into two classes, namely, the androgens (19-norandrostane or estrane derivatives), and $17 \alpha$-hydroxyprogesterones. In case of the compounds belonging to the androgen category, $17 \alpha$-substituents like ethyl, methyl, etc., lead to increase in the oral bioavailability (e.g., Ethisterone). Removal of the methyl group at C19 position and chlorination at $\mathrm{C} 21$ or methylation at $\mathrm{C} 18$ provided norethisterone, whose activity was further enhanced by chlorine substitution at $\mathrm{C} 21$ or by the addition of methyl group at C18 (e.g., Norgestrel). Acylation of 17 $\beta$-hydroxyl group of Norethisterone extended the duration of its action. Synthetic progestins include medroxyprogesterone acetate and norethisterone (first generation), norgestrel and levonorgestrel (second generation), etonogestrel and nosgestimate (third generation), drospirenone and trimegestone (fourth generation), etc. [89].

\subsection{Gonadotropin-Releasing Hormone Receptor (GnRHR)}

The GnRH (Fig.4.2f) is a decapeptide that plays a pivotal role in regulating the reproductive functions by functioning through the hypothalamic-pituitary gonadal (HPG) axis. The action of GnRH is mediated by the action of GnRHR, which 
belongs to the rhodopsin-like GPCR superfamily. GnRHR is expressed in various reproductive cancers, such as the prostate, ovarian, endometrial, and the breast cancer, as well as the nonreproductive cancer types. In these tumors, the GnRH functions as a paracrine-autocrine growth factor and displays a strong anticancer activity. The GnRHR (for 3D structure, refer to Flanagan C.A. et al.) consists of seven transmembrane (TM) domains, as well as an extracellular amino-terminal domain that contains 35 amino acids, along with two putative glycosylation sites. However, it lacks the carboxy-terminal cytoplasmic tail resulting in slow internalization and desensitization of the receptor. The membrane-spanning segments are highly conserved, while the loops and the termini constitute to be the variable regions $[47,82,107,108]$.

\subsubsection{Gonadotropin-Releasing Hormone Receptor: Recognition Domain and Receptor-Ligand Interactions}

The receptor $(\mathrm{R})$ exists in an equilibrium between an inactive $\mathrm{R}$, which does not activate $\mathrm{G}$ proteins and is stabilized by an antagonist, and an active $\mathrm{R}^{*}$ conformation, which activates $\mathrm{G}$ proteins and is stabilized by agonists, depending on the presence or absence of the ligand. The ligands of the receptor interact with the variable, extracellular half of the receptor molecule. The membrane-spanning receptor domain transmits the signal generated upon ligand binding to the cytosolic receptor surface, which further interacts with the G protein. The GnRHR must exist in a silent state that does not activate the G protein, in order to transduce the signals mediated by agonists across the cell membrane. Binding of the agonist causes transition from the silent state and leads to the binding and activation of $G$ proteins, situated on the opposite side of the cell membrane. Thus, agonists like GnRH act as allosteric activators of the receptor. The primary features of the inactive form of the receptor include closed G-protein-binding pocket, a hydrogen-bonding network, and a hydrophobic barrier. Binding of the ligand activates the receptor, causing rotation and change in the interfaces of specific TM segments, leading to opening of the hydrophobic barrier, movement of specific amino acid residues toward the interior of the TM bundle, and ultimately opening of the cytoplasmic surface cleft that allows contact and binding of the G-proteins [108]. The structure of the recognition domain or LBD of the receptor, involved in binding, depends on the type of the ligand such as a neurotransmitter, a glycoprotein hormone, and a peptide. In the case of a neurotransmitter, the TM domains (TMDs) themselves form the LBP to facilitate ligand binding. The amino-terminal domain of the receptor, encompassing the high-affinity ligand-binding site, has been reported to be recognition domain for glycoprotein hormones. A high-affinity binding site for the peptide-based ligands include both extracellular and TM residues [109]. 


\subsubsection{Gonadotropin-Releasing Hormone Receptor Pathway}

Binding of the hormone causes coupling of GnRHR to $G_{\alpha q / 11}$ protein, which stimulates the phospholipase $\mathrm{C} \beta$ (PLC $\beta$ ) activity. This leads to the enhancement of intracellular levels of inositol triphosphate (IP3) and diacylglycerol (DAG), further causing intracellular mobilization of $\mathrm{Ca}^{2+}$ ions and activation of the protein kinase $\mathrm{C}$ (PKC). These downstream effects lead to the activation of various signaling pathways, which operate through the MAPK reaction cascade. Phospholipase D and phospholipase A2 are also activated in a sequential manner. These biochemical pathways are vital in eliciting the GnRH-mediated downstream effects, such as gonadotropin synthesis and secretion [47]. Figure $4.1 \mathrm{~b}$ provides a schematic representation of the GnRHR, a GPCR, and the intracellular pathway activated upon binding of $\mathrm{GnRH}$ to the receptor.

\subsubsection{Structure-Activity Relationships for Selective Ligand Binding to GnRHR}

Amino- and carboxy-terminal residues are critical for receptor binding and activation. The presence of achiral glycine (Gly) or D-amino acids is essential at position 6, to facilitate active conformation in the folded state. $\mathrm{His}^{2}$, Trp ${ }^{3}$, as well as pGlu ${ }^{1}$ of the GnRH decapeptide possess significant roles in receptor activation. Substitution of amino acid residues located outside the amino-terminal domain is speculated to affect the receptor activation, due to the conformational changes in the ligand that may occur upon binding to the receptor [110].

The subsequent section of the chapter highlights the approaches explored for receptor targeting as well as an overview of mechanisms involved therein.

\section{Approaches for Receptor Targeting: Relevance to Cancers of Reproductive System}

Table 4.2 provides an overview of drug molecules developed to target receptors predominantly expressed in the cancers of the reproductive system. Fig.4.3 provides a schematic layout of the classification of the agents (ligands, agonist, antagonists, modulators, etc.), either endogenously present and/or synthesized for targeting to the aforementioned receptors.

\subsection{Mechanisms of Receptor Targeting and Implications in Cancers of Reproductive System}

Several mechanisms employed for targeting receptors predominantly expressed in the cancers of reproductive system have been summarized and supported by relevant case studies in this section. 


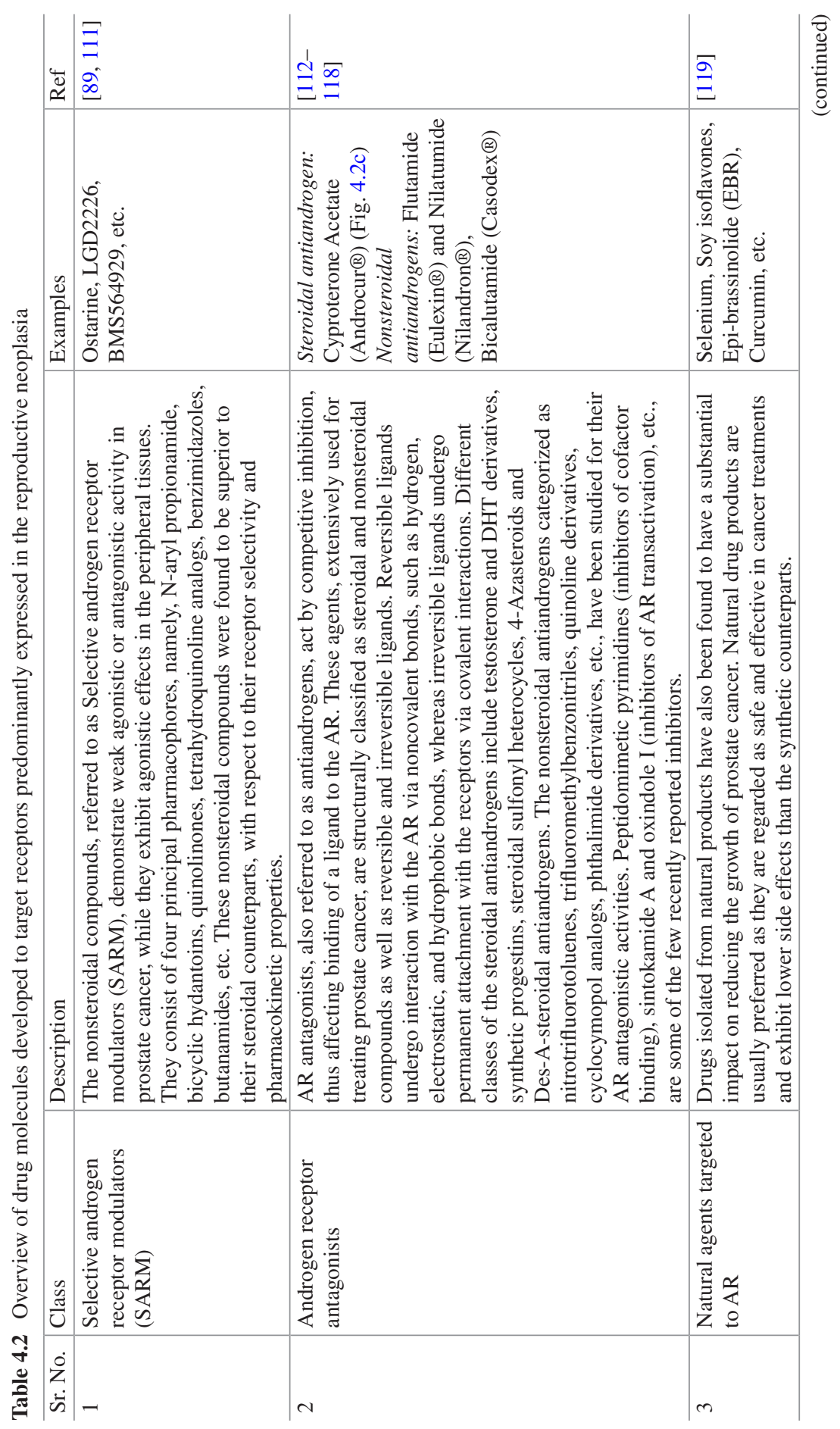




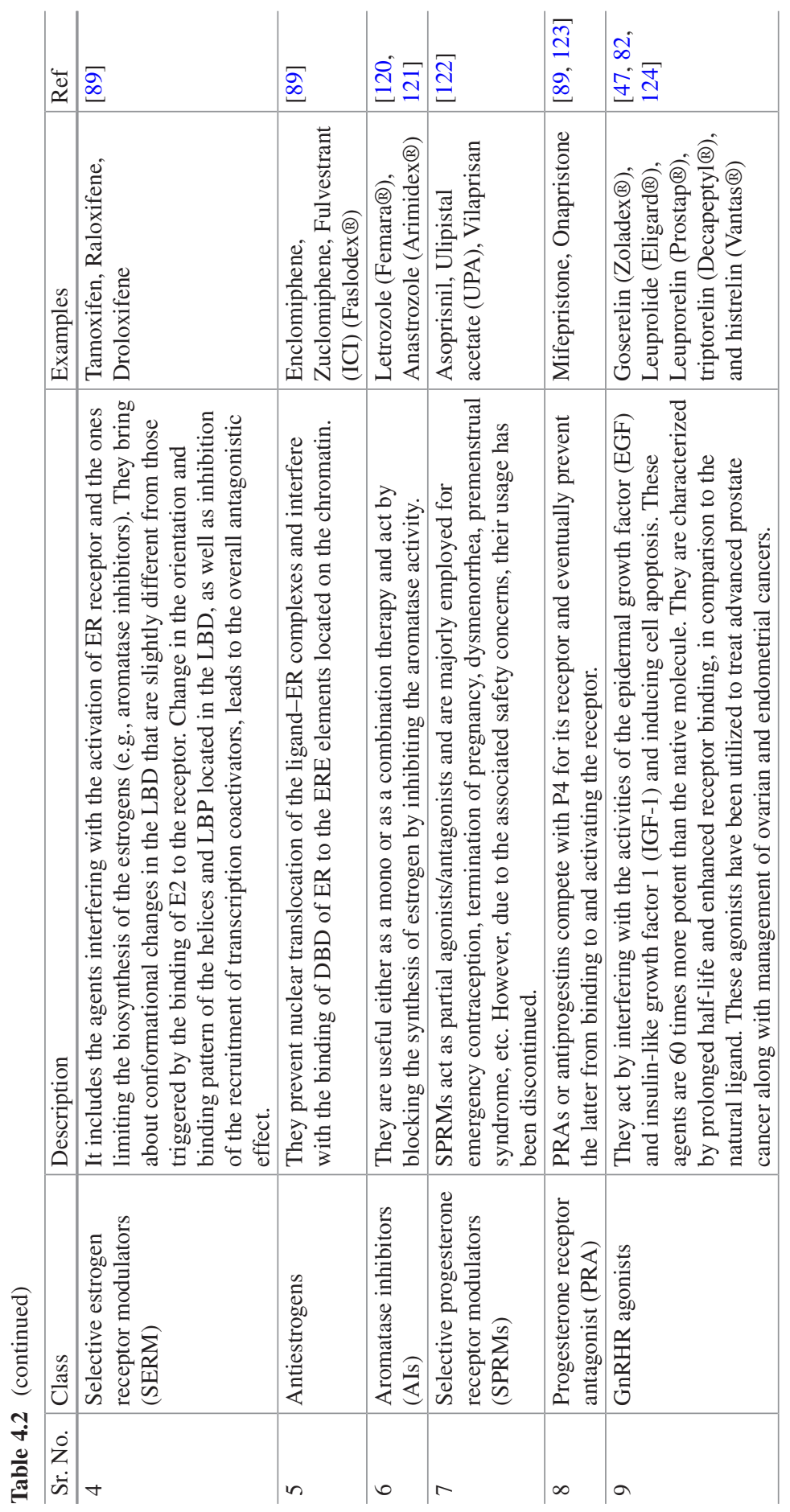




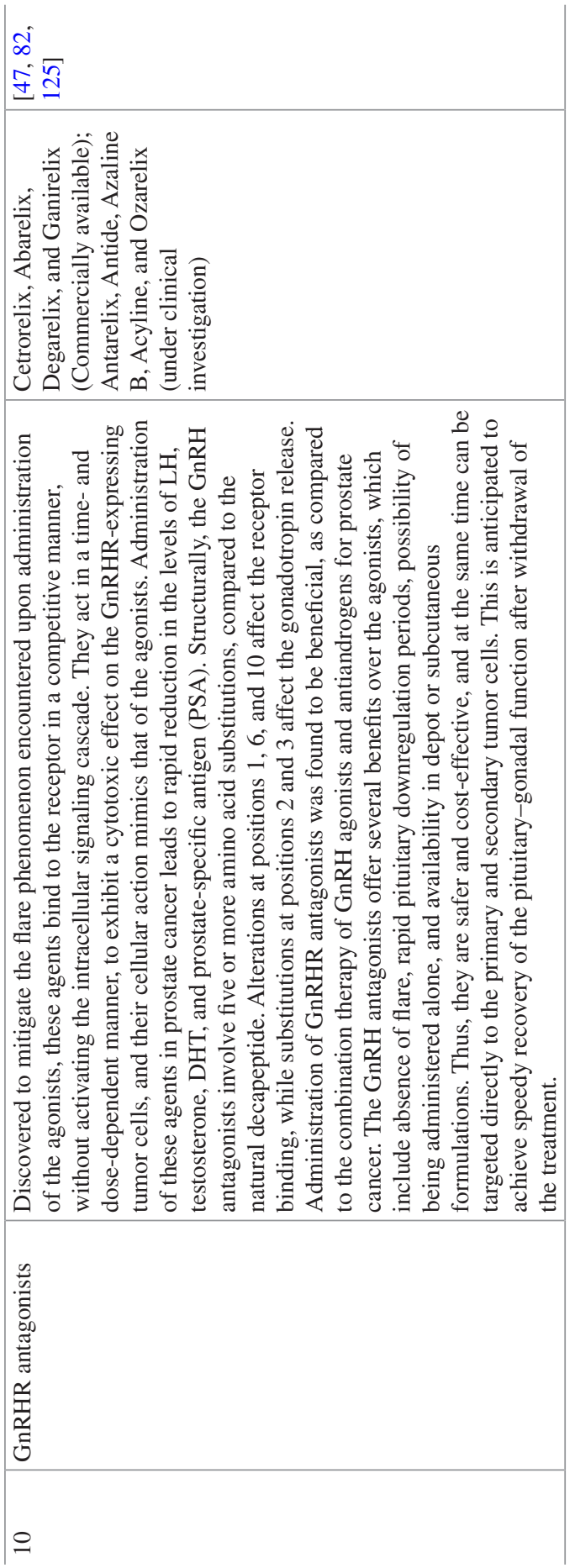




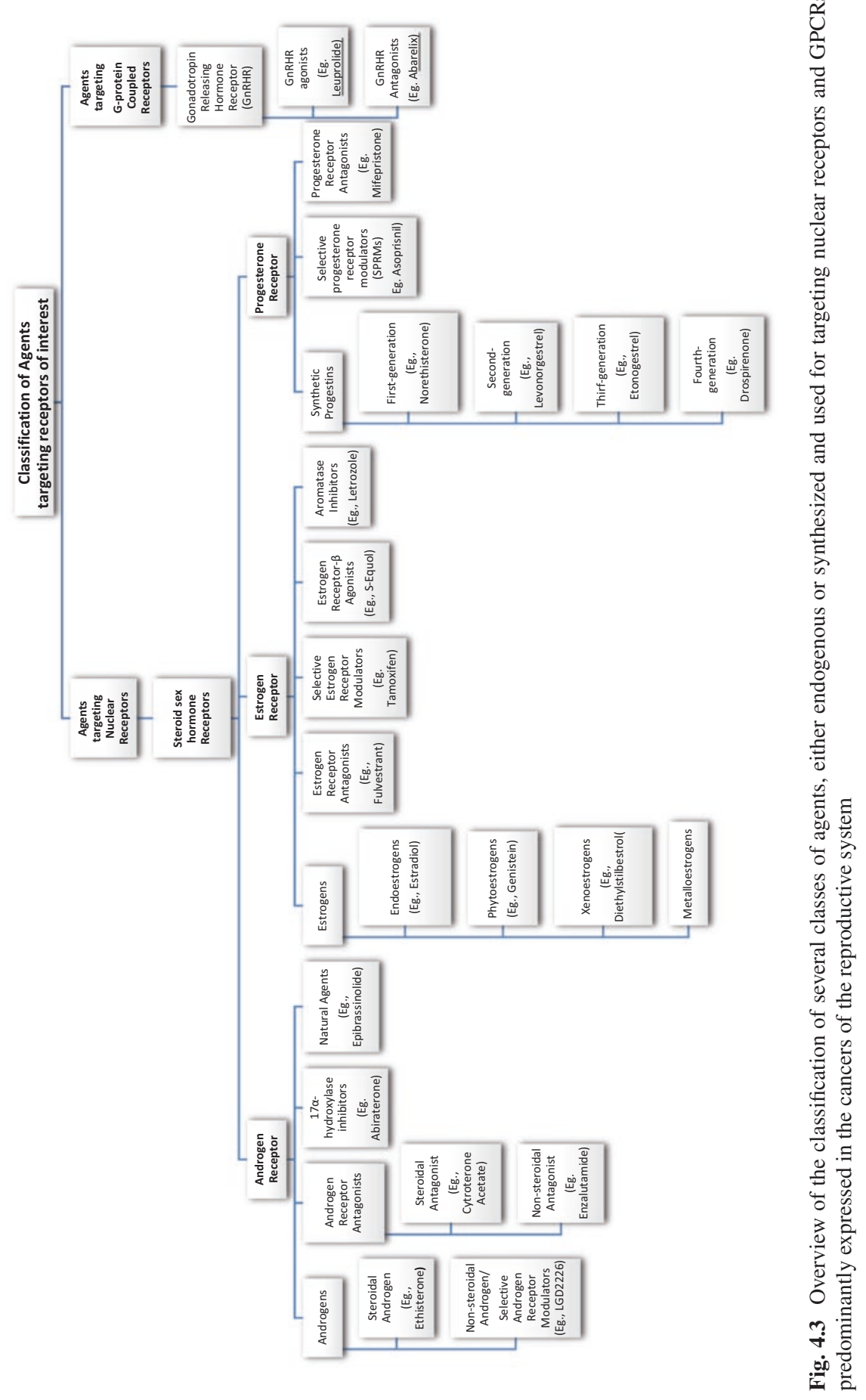




\subsubsection{Prodrug Approach}

The limitations of chemotherapy, such as toxicity and lack of selectivity, can be addressed with different approaches that selectively target the existing drugs to the malignant cells and through the development of nontoxic forms of anticancer agents, which may be specifically activated in the tumor tissues. Selective activation of prodrugs into active anticancer agents, in the vicinity of tumor tissues, can be mediated either by metabolic activity or by spontaneous chemical breakdown. Investigations have been carried out for targeting advanced mCRPC by prodrug approach by means of targeting prostate cancer-specific antigens such as prostatespecific antigens (PSA), prostate-specific membrane antigens (PSMA), CD147, heat shock proteins (HSPs), leutinizing hormone-releasing hormone (LHRH) receptor, epithelial cell adhesion molecules, etc., and prostate-specific enzymes such as cathepsin or matrix metalloproteinase. Numerous PSMA-targeting molecules, which include monoclonal antibodies (mAbs), antibody-drug conjugates (ADCs), antibody fragments (Fabs), peptides, and aptamers, have been developed in the form of prodrugs or nanoparticles. In recent times, a prodrug, namely vinblastine-Noxide (CPD100), was developed for the treatment of ovarian cancer by Cascade Prodrug, a US-based pharmaceutical company. This compound, formulated as sphingomyelin-cholesterol liposomes, is converted into its parent compound, vinblastine, under hypoxic conditions. This formulation was found to be highly successful in the preliminary studies and if successful in clinical trials, it will be the first-of-its-kind of chemotherapeutic agent to demonstrate anticancer activity due to the hypoxic microenvironment present in the solid tumors [126-128].

\subsubsection{Indirect Targeting of the Receptor}

Malignancies specific to prostate gland can also be controlled by indirect targeting of AR-targeted drugs such as agonists, antagonists, partial agonists, and antagonists. Indirect targeting approach can also be considered such as targeting small molecules like $17 \alpha$-hydroxylase involved in the de-novo synthesis of androgens by drugs such as Abiraterone. Abiraterone, in combination with prednisone, was approved in 2012 as the first-line therapy against mCRPCs, before commencing the administration of the conventional chemotherapy. Tamoxifen is the oldest and the most extensively studied SERM. It is a prodrug with low ER affinity, and gets converted into active metabolites such as endoxifen or afimoxifene through metabolism in the liver. These active metabolites demonstrate 30-100 times greater affinity toward the target receptors, as compared to tamoxifen. Substances involved in the synthesis of estrogen, such as aromatase, can also be considered as alternative targets for the treatment of ovarian cancers. The AIs blocks the protein involved in estrogen synthesis, but their usage is limited for the postmenopausal women, as they do not inhibit estrogen synthesis in the ovaries of the premenopausal women. Fulvestrant (Faslodex $\AA)$, Anastrozole (Arimidex $\left.{ }^{\circledR}\right)$, Letrozole (Femara $\left.{ }^{\circledR}\right)$, and Exemestane (Aromasin $®$ ) are examples of the AIs, which are useful either as a monotherapy or combinatorial therapy, during the treatment of ovarian cancer [121, 129-131]. 


\subsubsection{Molecular-Based Targeting Approach: Gene Therapy}

Gene therapy has been explored as one of the advanced ER-targeting strategies. Recently, an innovative effort provided a strong confirmation that enhanced estrogen signaling is responsible for the growth of the cervical tumor. Enhanced expression of Cyclin D1, ERs, and aromatase is significantly associated with the tumor growth. Hence, blocking the estrogen pathway, particularly to decrease the ER activity, can be a rational approach to activate p53 and retinoblastoma protein $(\mathrm{pRb})$, along with lowering the expression of HPV E6 and E7. This approach has been utilized to block ER-mediated tumor growth in cervical cancer cells, by transfection using adenovirus (AD) as a gene carrier [132].

\subsubsection{Novel/Nano Drug Delivery Systems}

Different approaches of drug delivery are being employed to target receptors expressed in reproductive neoplasia. Promising results of raloxifene in clinical trials has suggested for an improvement in the efficacy of this drug by exploring novel delivery systems like nanoformulations or through the development of raloxifene analogs. Raloxifene has been effectively encapsulated in nanoparticles, such as styrene-maleic acid (SMA) micelles, which demonstrated superior pharmacokinetic profile than the free drug $[95,133]$.

As discussed in Table 4.2, Progesterone and GnRH receptors can be directly targeted by means of agonists, antagonists, or partial agonists and antagonists. Extensive research is in progress for finding numerous other potential approaches for targeting these receptor for the treatment of malignancies related to organs of reproductive system.

\section{Receptor-Targeted Ligands in Clinical Development: Preclinical and Clinical Studies}

\subsection{Preclinical Studies}

Table 4.3 describes the preclinical studies for drugs targeted to the receptors predominantly expressed in cancers of the reproductive system.

\subsection{Clinical Trials}

Table 4.4 gives an overview of the clinical trials that have been conducted to target the receptors relevant to the cancers of the reproductive system. 


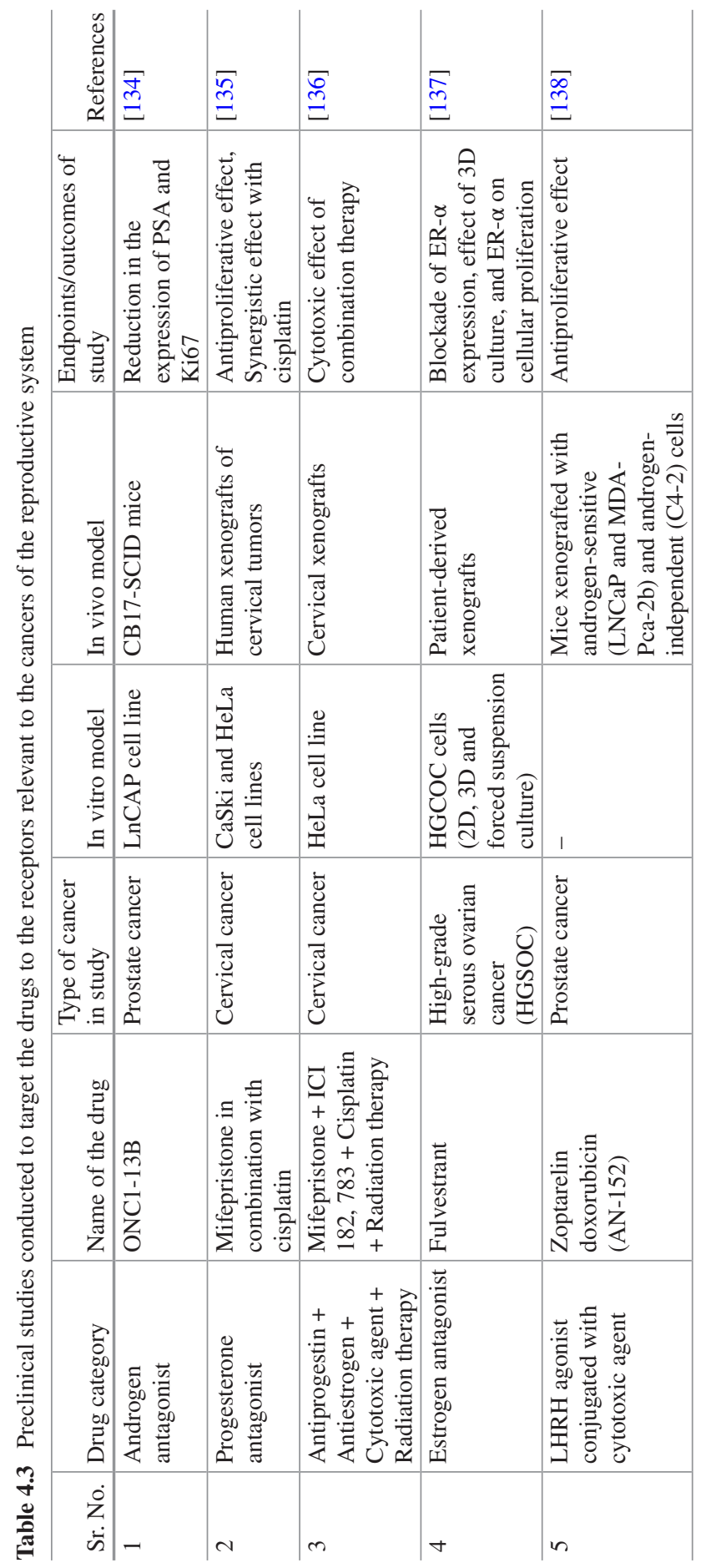




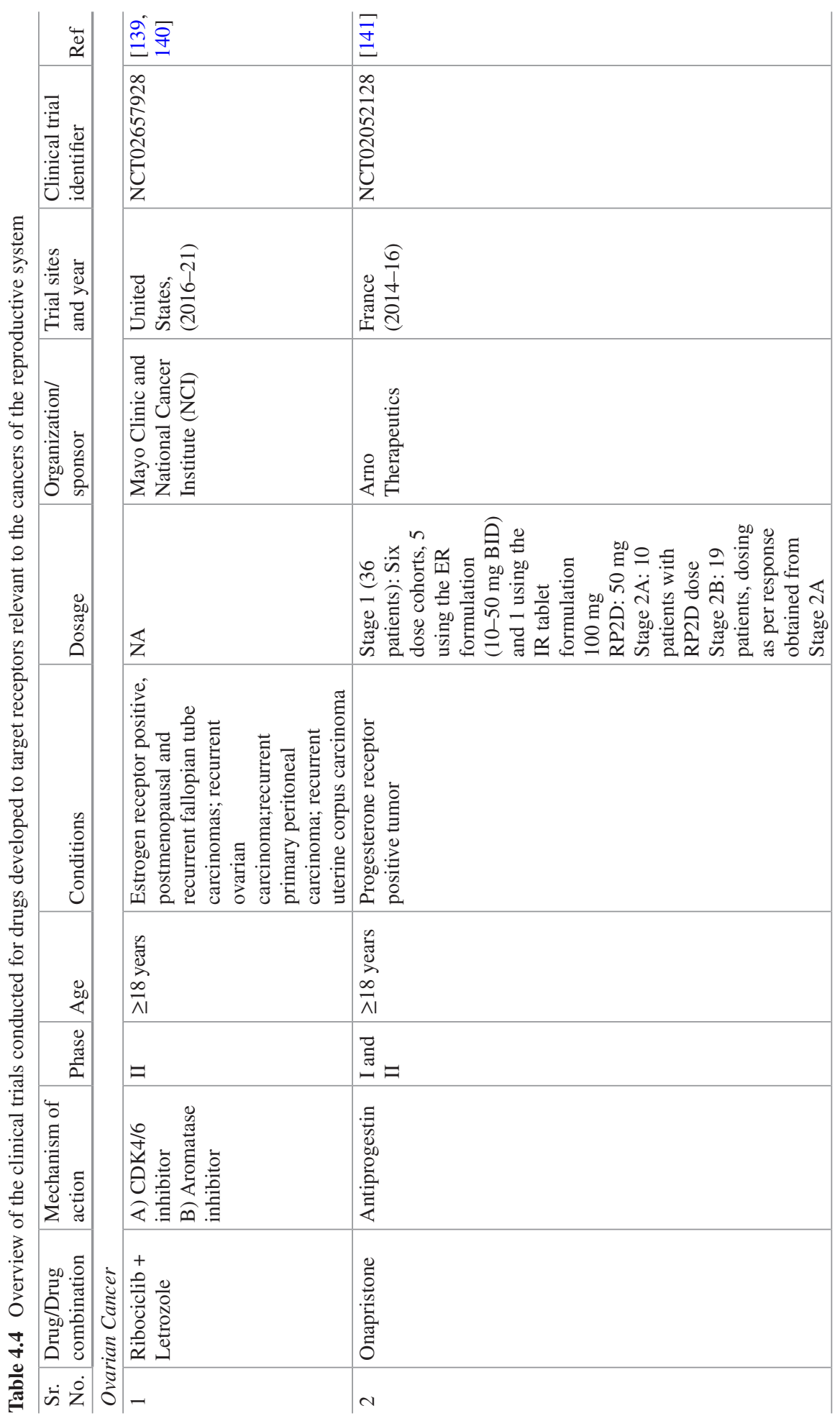




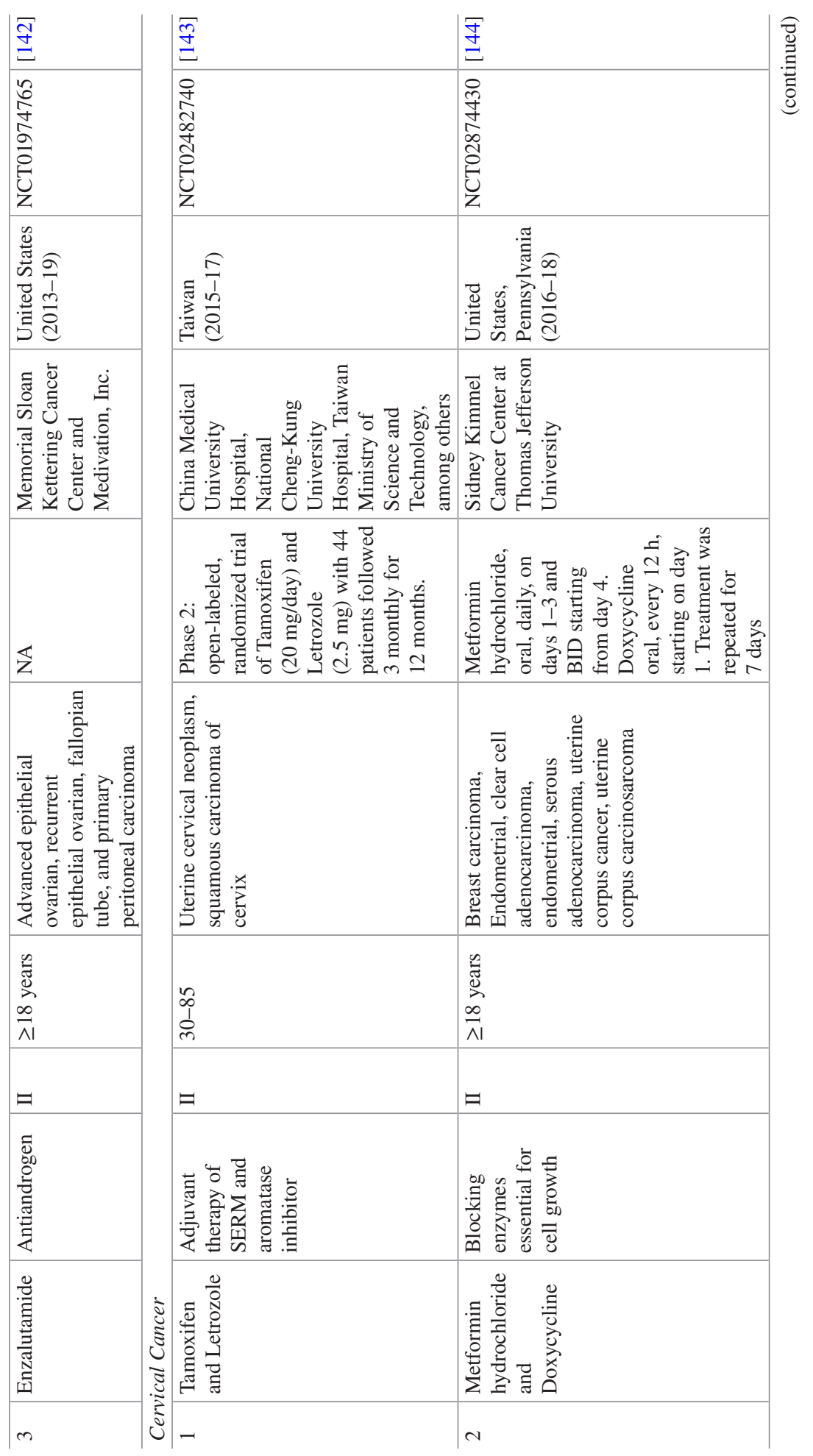




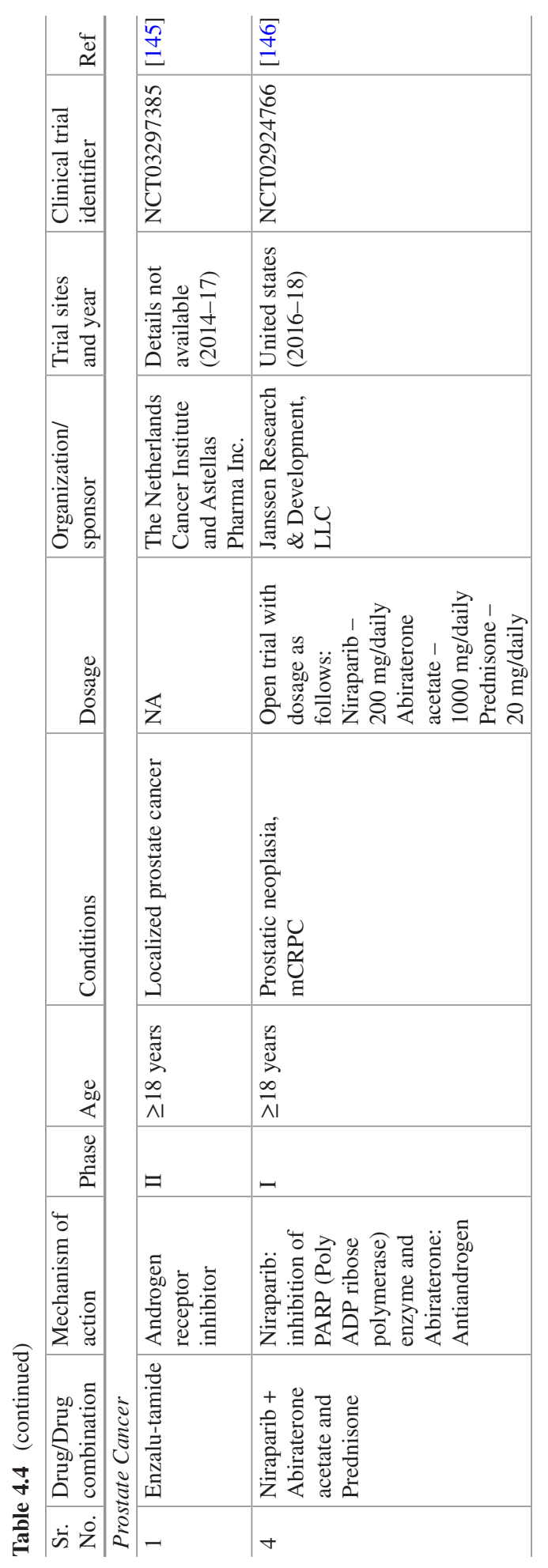




\section{Conclusion and Critical Comments}

Carcinogenesis in the different organs of the reproductive system, particularly, prostate, ovarian, and cervical tissues, involves aberrant expression of various physiological receptors belonging to different superfamilies. Structural and pharmacological role of four predominant receptors, namely, AR, ER, PR (sex steroid nuclear receptors), and GnRHR (GPCRs) has been highlighted in this chapter. Moreover, strategies and molecules developed for targeting these receptors, for formulating clinically relevant anticancer therapeutics, have been put forth and supported by the ongoing preclinical and clinical studies. We speculate that a combinatorial therapy comprising receptor-targeted ligands/agents, with clinically acceptable cytotoxic drugs, as well as targeting moieties such as antibodies (antibody-drug conjugates) and use of nano- and novel carriers for drug delivery, will enhance the overall antineoplastic effect. Considerable research has been conducted in deciphering the role of the AR and GnRHR in the cancers of the reproductive system and efforts to target these receptors have been commenced. We anticipate similar investigations to be conducted for ER and PR receptors in the near future.

\section{References}

1. Chung S-H. Targeting female hormone receptors as cervical cancer therapy. Trends Endocrinol Metab. 2015;26(8):399-401.

2. Zhang Q, Madden NE, Wong AST, Chow BKC, Lee LTO. The role of endocrine G proteincoupled receptors in ovarian cancer progression. Front Endocrinol. 2017;8:66.

3. Data on specific cancers: World Cancer Research Fund International; [cited 2018 July 20]. Available from: https://www.wcrf.org/int/cancer-facts-figures/data-specific-cancers.

4. Sharifi N, Salmaninejad A, Ferdosi S, Bajestani AN, Khaleghiyan M, Estiar MA, et al. HER2 gene amplification in patients with prostate cancer: evaluating a CISH-based method. Oncol Lett. 2016;12(6):4651-8.

5. Ginsburg O, Bray F, Coleman MP, Vanderpuye V, Eniu A, Kotha SR, et al. The global burden of women's cancers: a grand challenge in global health. Lancet. 2017;389(10071):847-60.

6. Townsley C. Cervical cancer. Elsevier Inc; 2007. Ontario, Canada.

7. Friese K, Kost B, Vattai A, Marmé F, Kuhn C, Mahner S, et al. The G protein-coupled estrogen receptor (GPER/GPR30) may serve as a prognostic marker in early-stage cervical cancer. J Cancer Res Clin Oncol. 2018;144(1):13-9.

8. Gharwan H, Bunch K, Annunziata C. The role of reproductive hormones in epithelial ovarian carcinogenesis. Endocrine Relat Cancer. 2015;22(6):R339-63.

9. Lukanova A, Kaaks R. Endogenous hormones and ovarian cancer: epidemiology and current hypotheses. Cancer Epidemiol Prev Biomarkers. 2005;14(1):98-107.

10. Bowtell DD. The genesis and evolution of high-grade serous ovarian cancer. Nat Rev Cancer. 2010;10(11):803.

11. Daniilidis A, Karagiannis V. Epithelial ovarian cancer. Risk factors, screening and the role of prophylactic oophorectomy. Hippokratia. 2007;11(2):63.

12. Bostwick DG, Burke HB, Djakiew D, Euling S, Ho SM, Landolph J, et al. Human prostate cancer risk factors. Cancer. 2004;101(S10):2371-490. 
13. White N, Burnstock G. P2 receptors and cancer. Trends Pharmacol Sci. 2006;27(4):211-7.

14. Roger S, Jelassi B, Couillin I, Pelegrin P, Besson P, Jiang L-H. Understanding the roles of the P2X7 receptor in solid tumour progression and therapeutic perspectives. Biochim Biophys Acta. 2015;1848(10):2584-602.

15. Ramírez A, Camacho J. The human papilloma virus-ion channel link in cancer: an alternative opportunity for diagnosis and therapy. Human papillomavirus and related diseases-from bench to bedside-research aspects. InTech; 2012. Belgium.

16. Abdul M, Hoosein N. N-methyl-D-aspartate receptor in human prostate cancer. J Membr Biol. 2005;205(3):125-8.

17. Abdul M, Mccray SD, Hoosein NM. Expression of gamma-aminobutyric acid receptor (subtype A) in prostate cancer. Acta Oncol. 2008;47(8):1546-50.

18. Venuti A, Salani D, Manni V, Poggiali F, Bagnato A. Expression of endothelin 1 and endothelin A receptor in HPV-associated cervical carcinoma: new potential targets for anticancer therapy. FASEB J. 2000;14(14):2277-83.

19. Kandalaft LE, Facciabene A, Buckanovich RJ, Coukos G. Endothelin B receptor, a new target in cancer immune therapy. Clin Cancer Res. 2009;15(14):4521-8.

20. Cirilli A, Simeone P, Muller A, Bagnato A, Venuti A. Targeting endothelin receptor type A in human cervical carcinoma cells. J Cardiovasc Pharmacol. 2004;44:S72-5.

21. Sánchez-Hernández PE, Ramirez-Dueñas MG, Albarran-Somoza B, García-Iglesias T, del Toro-Arreola A, Franco-Topete R, et al. Protease-activated receptor-2 (PAR-2) in cervical cancer proliferation. Gynecol Oncol. 2008;108(1):19-26.

22. Cornelio DB, Meurer L, Roesler R, Schwartsmann G. Gastrin-releasing peptide receptor expression in cervical cancer. Oncology. 2007;73(5-6):340-5.

23. Cornelio DB, Meurer L, Schwartsmann G, Roesler R. The gastrin-releasing peptide receptor as a marker of dysplastic alterations in cervical epithelial cells. Oncology. 2012;82(2):90-7.

24. Liu C, Ding L, Bai L, Chen X, Kang H, Hou L, et al. Folate receptor alpha is associated with cervical carcinogenesis and regulates cervical cancer cells growth by activating ERK1/2/cFos/c-Jun. Biochem Biophys Res Commun. 2017;491(4):1083-91.

25. Bagnato A, Salani D, Di Castro V, Wu-Wong JR, Tecce R, Nicotra MR, et al. Expression of endothelin 1 and endothelin A receptor in ovarian carcinoma: evidence for an autocrine role in tumor growth. Cancer Res. 1999;59(3):720-7.

26. Bagnato A, Spinella F, Rosano L. Emerging role of the endothelin axis in ovarian tumor progression. Endocr Relat Cancer. 2005;12(4):761-72.

27. Lin C, Majoor CJ, Roelofs JJ, de Kruif MD, Horlings HM, Borensztajn K, et al. Potential importance of protease activated receptor (PAR)-1 expression in the tumor stroma of nonsmall-cell lung cancer. BMC Cancer. 2017;17(1):113.

28. Jahan I, Fujimoto J, Alam SM, Sato E, Sakaguchi H, Tamaya T. Role of protease activated receptor-2 in tumor advancement of ovarian cancers. Ann Oncol. 2007;18(9):1506-12.

29. Tang J, Li Z, Lu L, Cho CH, editors. $\beta$-Adrenergic system, a backstage manipulator regulating tumour progression and drug target in cancer therapy. Seminars in cancer biology. Elsevier; 2013. Hong Kong, China.

30. Fleischmann A, Waser B, Reubi JC. Overexpression of gastrin-releasing peptide receptors in tumor-associated blood vessels of human ovarian neoplasms. Anal Cell Pathol. 2007;29(5):421-33.

31. Cornelio D, Roesler R, Schwartsmann G. Gastrin-releasing peptide receptor as a molecular target in experimental anticancer therapy. Ann Oncol. 2007;18(9):1457-66.

32. Filardo EJ, Thomas P. Minireview: G protein-coupled estrogen receptor-1, GPER-1: its mechanism of action and role in female reproductive cancer, renal and vascular physiology. Endocrinology. 2012;153(7):2953-62.

33. Qian H, Xuan J, Liu Y, Shi G. Function of G-protein-coupled estrogen receptor-1 in reproductive system tumors. J Immunol Res. 2016;2016:1.

34. Siu MK, Kong DS, Chan HY, Wong ES, Ip PP, Jiang L, et al. Paradoxical impact of two folate receptors, FR $\alpha$ and RFC, in ovarian cancer: effect on cell proliferation, invasion and clinical outcome. PLoS One. 2012;7(11):e47201. 
35. Henriksen R, Dizeyi N, Abrahamsson P-A. Expression of serotonin receptors 5-HT1A, 5-HT1B, 5-HT2B and 5-HT4 in ovary and in ovarian tumours. Anticancer Res. 2012;32(4):1361-6.

36. Gohji K, Kitazawa S, Tamada H, Katsuoka Y, Nakajima M. Expression of endothelin receptor a associated with prostate cancer progression. J Urol. 2001;165(3):1033-6.

37. Nelson JB, Udan MS, Guruli G, Pflug BR. Endothelin-1 inhibits apoptosis in prostate cancer. Neoplasia. 2005;7(7):631-7.

38. Black PC, Mize GJ, Karlin P, Greenberg DL, Hawley SJ, True LD, et al. Overexpression of protease-activated receptors-1,-2, and-4 (PAR-1,-2, and-4) in prostate cancer. Prostate. 2007;67(7):743-56.

39. Yu G, Jiang P, Xiang Y, Zhang Y, Zhu Z, Zhang C, et al. Increased expression of protease-activated receptor 4 and trefoil factor 2 in human colorectal cancer. PLoS One. 2015;10(4):e0122678.

40. Yuan T-C, Lin M-F. Protease-activated receptor 1: a role in prostate cancer metastasis. Clin Prostate Cancer. 2004;3(3):189-91.

41. Braadland PR, Ramberg HA, Grytli HH, Taskén KA. $\beta$-adrenergic receptor signaling in prostate cancer. Front Oncol. 2015;4:375.

42. Nagasaki S, Nakamura Y, Maekawa T, Akahira J, MikiY, Suzuki T, et al. Immunohistochemical analysis of gastrin-releasing peptide receptor (GRPR) and possible regulation by estrogen receptor $\beta c x$ in human prostate carcinoma. Neoplasma. 2012;59(2):224-32.

43. Cao W, Li F, Yao J, Yu J. Prostate specific G protein coupled receptor is associated with prostate cancer prognosis and affects cancer cell proliferation and invasion. BMC Cancer. 2015;15(1):915.

44. Weng J, Wang J, Hu X, Wang F, Ittmann M, Liu M. PSGR2, a novel G-protein coupled receptor, is overexpressed in human prostate cancer. Int J Cancer. 2006;118(6):1471-80.

45. Patel N, Itakura T, Jeong S, Liao C-P, Roy-Burman P, Zandi E, et al. Expression and functional role of orphan receptor GPR158 in prostate cancer growth and progression. PLoS One. 2015;10(2):e0117758.

46. Guo R, Kasbohm EA, Arora P, Sample CJ, Baban B, Sud N, et al. Expression and function of lysophosphatidic acid LPA1 receptor in prostate cancer cells. Endocrinology. 2006;147(10):4883-92.

47. Limonta P, Manea M. Gonadotropin-releasing hormone receptors as molecular therapeutic targets in prostate cancer: current options and emerging strategies. Cancer Treat Rev. 2013;39(6):647-63.

48. Dizeyi N, Bjartell A, Hedlund P, Tasken K, Gadaleanu V, Abrahamsson P-A. Expression of serotonin receptors $2 \mathrm{~B}$ and 4 in human prostate cancer tissue and effects of their antagonists on prostate cancer cell lines. Eur Urol. 2005;47(6):895-900.

49. Dizeyi N, Bjartell A, Nilsson E, Hansson J, Gadaleanu V, Cross N, et al. Expression of serotonin receptors and role of serotonin in human prostate cancer tissue and cell lines. Prostate. 2004;59(3):328-36.

50. Oh D-Y, Kim S, Choi Y-L, Cho YJ, Oh E, Choi J-J, et al. HER2 as a novel therapeutic target for cervical cancer. Oncotarget. 2015;6(34):36219.

51. Soonthornthum T, Arias-Pulido H, Joste N, Lomo L, Muller C, Rutledge T, et al. Epidermal growth factor receptor as a biomarker for cervical cancer. Ann Oncol. 2011;22(10):2166-78.

52. Kuramoto H, Hongo A, Liu YX, Ojima Y, Nakamura K, Seki N, et al. Immunohistochemical evaluation of insulin-like growth factor I receptor status in cervical cancer specimens. Acta Med Okayama. 2008;62(4):251-9.

53. Frumovitz M, Sood AK. Vascular endothelial growth factor (VEGF) pathway as a therapeutic target in gynecologic malignancies. Gynecol Oncol. 2007;104(3):768-78.

54. Lopez-Pulido EI, Muñoz-Valle JF, Del Toro-Arreola S, Jave-Suárez LF, Bueno-Topete MR, Estrada-Chávez C, et al. High expression of prolactin receptor is associated with cell survival in cervical cancer cells. Cancer Cell Int. 2013;13(1):103.

55. Peng J, Qi S, Wang P, Li W, Liu C, Li F. Diagnosis and prognostic significance of c-Met in cervical cancer: a meta-analysis. Dis Markers. 2016;2016:1. 
56. Choi CH, Chung J-Y, Kim J-H, Kim B-G, Hewitt SM. Expression of fibroblast growth factor receptor family members is associated with prognosis in early stage cervical cancer patients. J Transl Med. 2016;14(1):124.

57. Amler LC, Wang Y, Hampton G. HER2 as a therapeutic target in ovarian cancer. Ovarian cancer-clinical and therapeutic perspectives. InTech; 2012. Croatia.

58. Mehner C, Oberg AL, Goergen KM, Kalli KR, Maurer MJ, Nassar A, et al. EGFR as a prognostic biomarker and therapeutic target in ovarian cancer: evaluation of patient cohort and literature review. Genes Cancer. 2017;8(5-6):589.

59. Gotlieb WH, Bruchim I, Gu J, Shi Y, Camirand A, Blouin M-J, et al. Insulin-like growth factor receptor I targeting in epithelial ovarian cancer. Gynecol Oncol. 2006;100(2):389-96.

60. Matsumoto K, Umitsu M, De Silva DM, Roy A, Bottaro DP. Hepatocyte growth factor/MET in cancer progression and biomarker discovery. Cancer Sci. 2017;108(3):296-307.

61. Crickard K, Gross JL, Crickard U, Yoonessi M, Lele S, Herblin WF, et al. Basic fibroblast growth factor and receptor expression in human ovarian cancer. Gynecol Oncol. 1994;55(2):277-84.

62. Omar N, Yan B, Salto-Tellez M. HER2: an emerging biomarker in non-breast and non-gastric cancers. Pathogenesis. 2015;2(3):1-9.

63. Day KC, Hiles GL, Kozminsky M, Dawsey SJ, Paul A, Broses LJ, et al. HER2 and EGFR overexpression support metastatic progression of prostate cancer to bone. Cancer Res. 2017;77(1):74-85.

64. Wu J, Yu E. Insulin-like growth factor receptor-1 (IGF-IR) as a target for prostate cancer therapy. Cancer Metastasis Rev. 2014;33(2-3):607-17.

65. Yang J, Wu HF, Qian LX, Zhang W, Hua LX, Yu ML, et al. Increased expressions of vascular endothelial growth factor (VEGF), VEGF-C and VEGF receptor-3 in prostate cancer tissue are associated with tumor progression. Asian J Androl. 2006;8(2):169-75.

66. Kwabi-Addo B, Ozen M, Ittmann M. The role of fibroblast growth factors and their receptors in prostate cancer. Endocr Relat Cancer. 2004;11(4):709-24.

67. Deuster E, Jeschke U, Ye Y, Mahner S, Czogalla B. Vitamin D and VDR in gynecological cancers-a systematic review. Int J Mol Sci. 2017;18(11):2328.

68. Ivanova T, Petrenko A, Gritsko T, Vinokourova S, Eshilev E, Kobzeva V, et al. Methylation and silencing of the retinoic acid receptor- $\beta 2$ gene in cervical cancer. BMC Cancer. 2002;2(1):4.

69. Voutsadakis IA. Hormone receptors in serous ovarian carcinoma: prognosis, pathogenesis, and treatment considerations. Clin Med Insights Oncol. 2016;10:17-25.

70. Kaiser P, Körner M, Kappeler A, Aebi S. Retinoid receptors in ovarian cancer: expression and prognosis. Ann Oncol. 2005;16(9):1477-87.

71. Tan ME, Li J, Xu HE, Melcher K, Yong E-L. Androgen receptor: structure, role in prostate cancer and drug discovery. Acta Pharmacol Sin. 2015;36(1):3.

72. Christoforou P, Christopoulos PF, Koutsilieris M. The role of estrogen receptor $\beta$ in prostate cancer. Mol Med. 2014;20(1):427.

73. Chen R, Yu Y, Dong X. Progesterone receptor in the prostate: a potential suppressor for benign prostatic hyperplasia and prostate cancer. J Steroid Biochem Mol Biol. 2017;166:91-6.

74. Elix C, Pal SK, Jones JO. The role of peroxisome proliferator-activated receptor gamma in prostate cancer. Asian J Androl. 2018;20(3):238.

75. Hongmao S. A practical guide to rational drug design. Woodhead Publishing; 2015. Maryland, USA

76. Robinson-Rechavi M, Garcia HE, Laudet V. The nuclear receptor superfamily. J Cell Sci. 2003;116(4):585-6.

77. Zuo H, Wan Y. Nuclear receptors in skeletal homeostasis. Curr Top Dev Biol. 2017;125:71107. Elsevier.

78. Gao X, Loggie BW, Nawaz Z. The roles of sex steroid receptor coregulators in cancer. Mol Cancer. 2002;1(1):7.

79. de Almeida Chuffa LG, Lupi-Júnior LA, Costa AB, de Arruda Amorim JP, Seiva FRF. The role of sex hormones and steroid receptors on female reproductive cancers. Steroids. 2017;118:93-108. 
80. Mungenast F, Thalhammer T. Estrogen biosynthesis and action in ovarian cancer. Front Endocrinol. 2014;5:192.

81. Park S, Han JM, Cheon J, Hwang J-I, Seong JY. Apoptotic death of prostate cancer cells by a gonadotropin-releasing hormone-II antagonist. PLoS One. 2014;9(6):e99723.

82. Limonta P, Marelli MM, Mai S, Motta M, Martini L, Moretti RM. GnRH receptors in cancer: from cell biology to novel targeted therapeutic strategies. Endocr Rev. 2012;33(5):784-811.

83. Cheung LW, Yung S, Chan T-M, Leung PC, Wong AS. Targeting gonadotropin-releasing hormone receptor inhibits the early step of ovarian cancer metastasis by modulating tumormesothelial adhesion. Mol Ther. 2013;21(1):78-90.

84. Gao W, Bohl CE, Dalton JT. Chemistry and structural biology of androgen receptor. Chem Rev. 2005;105(9):3352-70.

85. Lonergan PE, Tindall DJ. Androgen receptor signaling in prostate cancer development and progression. J Carcinog. 2011;10.

86. Jernberg E, Bergh A, Wikström P. Clinical relevance of androgen receptor alterations in prostate cancer. Endocr Connect. 2017;6(8):R146-R61.

87. Zhu H, Zhu X, Zheng L, Hu X, Sun L, Zhu X. The role of the androgen receptor in ovarian cancer carcinogenesis and its clinical implications. Oncotarget. 2017;8(17):29395.

88. Munoz J, Wheler JJ, Kurzrock R. Androgen receptors beyond prostate cancer: an old marker as a new target. Oncotarget. 2015;6(2):592.

89. Foye WO. Foye's principles of medicinal chemistry. Lippincott Williams \& Wilkins; 2008. Philadelphia, USA.

90. Centenera MM, Selth LA, Ebrahimie E, Butler LM, Tilley WD. New opportunities for targeting the androgen receptor in prostate cancer. Cold Spring Harb Perspect Med. 2018:a030478.

91. Davey RA, Grossmann M. Androgen receptor structure, function and biology: from bench to bedside. Clin Biochem Rev. 2016;37(1):3.

92. Deroo BJ, Korach KS. Estrogen receptors and human disease. J Clin Invest. 2006;116(3):561-70.

93. Lee H-R, Kim T-H, Choi K-C. Functions and physiological roles of two types of estrogen receptors, ER $\alpha$ and $\mathrm{ER} \beta$, identified by estrogen receptor knockout mouse. Lab Anim Res. 2012;28(2):71-6.

94. Chen GG, Zeng Q, Tse GM. Estrogen and its receptors in cancer. Med Res Rev. 2008;28(6):954-74.

95. Di Zazzo E, Galasso G, Giovannelli P, Di Donato M, Castoria G. Estrogens and their receptors in prostate cancer: therapeutic implications. Front Oncol. 2018;8:2.

96. Sato T, Miyagawa S, Iguchi T. Estradiol-17ß. Handbook of hormones. Elsevier; 2015. p. 520e94G-4. Japan.

97. Farooq A. Structural and functional diversity of estrogen receptor ligands. Curr Top Med Chem. 2015;15(14):1372-84.

98. Gehm BD, McAndrews JM, Chien P-Y, Jameson JL. Resveratrol, a polyphenolic compound found in grapes and wine, is an agonist for the estrogen receptor. Proc Natl Acad Sci. 1997;94(25):14138-43.

99. Jordan VC, Mittal S, Gosden B, Koch R, Lieberman ME. Structure-activity relationships of estrogens. Environ Health Perspect. 1985;61:97.

100. Diep CH, Daniel AR, Mauro LJ, Knutson TP, Lange CA. Progesterone action in breast, uterine, and ovarian cancers. J Mol Endocrinol. 2015;54(2):R31-53.

101. Valadez-Cosmes P, Vázquez-Martínez ER, Cerbon M, Camacho-Arroyo I. Membrane progesterone receptors in reproduction and cancer. Mol Cell Endocrinol. 2016;434:166-75.

102. Sato T, Miyagawa S, Iguchi T. Progesterone. Handbook of hormones. Elsevier; 2015. p. 507e94A-3. Japan.

103. Daniel AR, Hagan CR, Lange CA. Progesterone receptor action: defining a role in breast cancer. Expert Rev Endocrinol Metab. 2011;6(3):359-69.

104. Yu Y, Liu L, Xie N, Xue H, Fazli L, Buttyan R, et al. Expression and function of the progesterone receptor in human prostate stroma provide novel insights to cell proliferation control. J Clin Endocrinol Metabol. 2013;98(7):2887-96. 
105. Lee P, Rosen DG, Zhu C, Silva EG, Liu J. Expression of progesterone receptor is a favorable prognostic marker in ovarian cancer. Gynecol Oncol. 2005;96(3):671-7.

106. Patel B, Elguero S, Thakore S, Dahoud W, Bedaiwy M, Mesiano S. Role of nuclear progesterone receptor isoforms in uterine pathophysiology. Hum Reprod Update. 2014;21(2):155-73.

107. Wang L, Chadwick W, Park S-S, Zhou Y, Silver N, Martin B, et al. Gonadotropin-releasing hormone receptor system: modulatory role in aging and neurodegeneration. CNS Neurol Disord Drug Targets. 2010;9(5):651-60.

108. Flanagan CA, Manilall A. Gonadotropin-releasing hormone $(\mathrm{GnRH})$ receptor structure and GnRH binding. Front Endocrinol. 2017;8:274.

109. Sealfon SC, Millar RP. Functional domains of the gonadotropin-releasing hormone receptor. Cell Mol Neurobiol. 1995;15(1):25-42.

110. Sealfon SC, Weinstein H, Millar RP. Molecular mechanisms of ligand interaction with the gonadotropin-releasing hormone receptor. Endocr Rev. 1997;18(2):180-205.

111. Bhasin S, Jasuja R. Selective androgen receptor modulators (SARMs) as function promoting therapies. Curr Opin Clin Nutr Metab Care. 2009;12(3):232.

112. Reid P, Kantoff P, Oh W. Antiandrogens in prostate cancer. Investig New Drugs. 1999;17(3):271-84.

113. Singh SM, Gauthier S, Labrie F. Androgen receptor antagonists (antiandrogens) structureactivity relationships. Curr Med Chem. 2000;7(2):211-47.

114. Haendler B, Cleve A. Recent developments in antiandrogens and selective androgen receptor modulators. Mol Cell Endocrinol. 2012;352(1-2):79-91.

115. Yang SH, Song C-H, Van HTM, Park E, Khadka DB, Gong E-Y, et al. SAR based design of nicotinamides as a novel class of androgen receptor antagonists for prostate cancer. J Med Chem. 2013;56(8):3414-8.

116. Tesei A, Leonetti C, Di Donato M, Gabucci E, Porru M, Varchi G, et al. Effect of small molecules modulating androgen receptor (SARMs) in human prostate cancer models. PLoS One. 2013;8(5):e62657.

117. Hwang DJ, Yang J, Xu H, Rakov IM, Mohler ML, Dalton JT, et al. Arylisothiocyanato selective androgen receptor modulators (SARMs) for prostate cancer. Bioorg Med Chem. 2006;14(19):6525-38.

118. Banuelos CA, Tavakoli I, Tien AH, Caley DP, Mawji NR, Li Z, et al. Sintokamide A is a novel antagonist of androgen receptor that uniquely binds activation function- 1 in its aminoterminal domain. J Biol Chem. 2016;291(42):22231-43.

119. Farooqi AA, Sarkar FH. Overview on the complexity of androgen receptor-targeted therapy for prostate cancer. Cancer Cell Int. 2015;15(1):7.

120. Li Y, Hu W, Fu S, Li J, Liu J, Kavanagh J. Aromatase inhibitors in ovarian cancer: is there a role? Int J Gynecol Cancer. 2008;18(4):600-14.

121. Ho S-M. Estrogen, progesterone and epithelial ovarian cancer. Reprod Biol Endocrinol. 2003;1(1):73.

122. Ali M, Al-Hendy A. Selective progesterone receptor modulators for fertility preservation in women with symptomatic uterine fibroids. Biol Reprod. 2017;97(3):337-52.

123. Chabbert-Buffet N, Meduri G, Bouchard P, Spitz IM. Selective progesterone receptor modulators and progesterone antagonists: mechanisms of action and clinical applications. Hum Reprod Update. 2005;11(3):293-307.

124. Hormone therapy for ovarian cancer: American Cancer Society; [cited 2018 October 20]. Available from: https://www.cancer.org/cancer/ovarian-cancer/treating/hormone-therapy. html.

125. Erdkamp F, Boone N, Janknegt R, Zambon V. GnRH agonists and antagonists in prostate cancer. Gene Biosimilars Initiative J. 2014;3:133-42.

126. Ast G. Drug-targeting strategies for prostate cancer. Curr Pharm Des. 2003;9(6):455-66.

127. Shah VM, Nguyen DX, Al Fatease A, Patel P, Cote B, Woo Y, et al. Liposomal formulation of hypoxia activated prodrug for the treatment of ovarian cancer. J Control Release. 2018;291:169-83. 
128. Barve A, Jin W, Cheng K. Prostate cancer relevant antigens and enzymes for targeted drug delivery. J Control Release. 2014;187:118-32.

129. Imamura Y, Sadar MD. Androgen receptor targeted therapies in castration-resistant prostate cancer: bench to clinic. Int J Urol. 2016;23(8):654-65.

130. Li Z, Bishop AC, Alyamani M, Garcia JA, Dreicer R, Bunch D, et al. Conversion of abiraterone to D4A drives anti-tumour activity in prostate cancer. Nature. 2015;523(7560):347.

131. Kothari R, Argenta P, Fowler J, Carter J, Shimp W. Antiestrogen therapy in recurrent ovarian cancer resulting in 28 months of stable disease: a case report and review of the literature. Arch Oncol. 2010;18(1-2):32.

132. Au WW, Abdou-Salama S, Al-Hendy A. Inhibition of growth of cervical cancer cells using a dominant negative estrogen receptor gene. Gynecol Oncol. 2007;104(2):276-80.

133. Sundararajan V, Chen S, Rosengren R. Raloxifene: promises and challenges as a drug treatment for castrate resistant prostate cancer. Enliven Toxicol Allied Clin Pharmacol. 2017;4(1):001.

134. Ivachtchenko AV, Mitkin OD, Kudan EV, Rjahovsky AA, Vorobiev AA, Trifelenkov AS, et al. Preclinical development of ONC1-13B, novel antiandrogen for prostate cancer treatment. J Cancer. 2014;5(2):133.

135. Jurado R, Lopez-Flores A, Alvarez A, García-López P. Cisplatin cytotoxicity is increased by mifepristone in cervical carcinoma: an in vitro and in vivo study. Oncol Rep. 2009;22(5):1237-45.

136. Segovia-Mendoza M, Jurado R, Mir R, Medina LA, Prado-Garcia H, Garcia-Lopez P. Antihormonal agents as a strategy to improve the effect of chemo-radiation in cervical cancer: in vitro and in vivo study. BMC Cancer. 2015;15(1):21.

137. Andersen CL, Sikora MJ, Boisen MM, Ma T, Christie A, Tseng G, et al. Active estrogen receptor-alpha signaling in ovarian cancer models and clinical specimens. Clin Cancer Res. 2017;23(14):3802-12.

138. Letsch M, Schally AV, Szepeshazi K, Halmos G, Nagy A. Preclinical evaluation of targeted cytotoxic luteinizing hormone-releasing hormone analogue AN-152 in androgen-sensitive and insensitive prostate cancers. Clin Cancer Res. 2003;9(12):4505-13.

139. Tripathy D, Bardia A, Sellers WR. Ribociclib (LEE011): mechanism of action and clinical impact of this selective cyclin-dependent kinase 4/6 inhibitor in various solid tumors. Clin Cancer Res. 2017;23(13):3251-62.

140. Ribociclib and letrozole in treating patients with relapsed ER positive ovarian, fallopian tube, primary peritoneal, or endometrial cancer [Internet]. Mayo Clinic. 2016 [cited October 25, 2018]. Available from: https://clinicaltrials.gov/ct2/show/record/NCT02657928?term=Riboc iclib+and+Letrozole \&cond=ovarian+cancer $\&$ rank $=2 \& v i e w=$ record.

141. Phase 1-2 study of onapristone in patients with progesterone receptor expressing cancers [Internet]. Arno Therapeutics. 2014 [cited October 25, 2018]. Available from: https://clinicaltrials.gov/ct2/show/record/NCT02052128?term=progesterone+receptor\&cond=Ovarian+ Cancer \&draw $=2 \&$ rank $=2$.

142. Enzalutamide in patients with androgen receptor positive (AR+) ovarian, primary peritoneal or fallopian tube cancer and one, two or three prior therapies [Internet]. Memorial Sloan Kettering Cancer Center. 2013 [cited October 26, 2018]. Available from: https://clinicaltrials.gov/ct2/show/study/NCT01974765?term=androgen+receptor\&cond=Ovarian+Cancer\&r ank $=2$.

143. A trial of tamoxifen and letrozole in recurrent and persistent squamous cell carcinoma of the cervix (TGOG1005) [Internet]. Buddhist Tzu Chi General Hospital. 2015 [cited October 26, 2018]. Available from: https://clinicaltrials.gov/ct2/show/record/NCT02482740?term=NCT $02482740 \&$ rank $=1$.

144. Metformin hydrochloride and doxycycline in treating patients with localized breast or uterine cancer [Internet]. Sidney Kimmel Cancer Center at Thomas Jefferson University. 2016 [cited October 27, 2018]. Available from: https://clinicaltrials.gov/ct2/show/record/NCT02874430 ?term=progesterone+receptor\&cond $=$ Cervical + Cancer\&rank $=2$. 
145. Dynamics of androgen receptor genomics and transcriptomics after neoadjuvant androgen ablation (DARANA) [Internet]. The Netherlands Cancer Institute. 2017 [cited October 27, 2018]. Available from: https://clinicaltrials.gov/ct2/show/record/NCT03297385?term=andro gen+receptor\&cond $=$ Prostate + Cancer $\&$ phase $=012 \&$ draw $=2$.

146. A safety and pharmacokinetics study of niraparib plus an androgen receptor-targeted therapy in men with metastatic castration-resistant prostate cancer (BEDIVERE) [Internet]. Janssen Research \& Development, LLC. 2016 [cited October 28, 2018]. Available from: https://clinicaltrials.gov/ct2/show/record/NCT02924766?term $=$ Erleada $+\% 28$ apalutamide\%29\&cond $=\mathrm{P}$ rostate+Cancer+Metastatic\&rank=6. 